\title{
IZAZOVI I PERSPEKTIVE SVAKODNEVNOG ŽIVOTA IZ ISKUSTVA ŽENA KOJE MUCAJU
}

\section{EVERYDAY CHALLENGES AND PERSPECTIVES OF WOMEN WHO STUTTER}

\author{
ANA LEKO KRHEN ${ }^{1}$, MARINA MILIĆ BABIĆ ${ }^{2}$, MAJA HOROVSKIJ \\ ${ }^{1}$ Odsjek za logopediju, Edukacijsko-rehabilitacijski fakultet, Sveučilište u Zagrebu, Zagreb, Hrvatska \\ ${ }^{2}$ Pravni fakultet, Studijski centar socijalnog rada, Sveučilište u Zagrebu, Zagreb, Hrvatska, \\ kontakt: marina.milic.babic@pravo.hr \\ ${ }^{3}$ Dom za odrasle osobe Skupnjak, Sv. Ivan Zelina.
}

Primljeno/Received: 07.12.2020.

Prihvaćeno/Accepted: 11.05.2021.

Sažetak: Cilj rada bio je dobiti uvid u svakodnevni život žena koje mucaju. U istraživanju je sudjelovalo šest osoba ženskog spola koje mucaju. Sudionice u prosjeku imaju 29 godina, žive u urbanim sredinama i visokoobrazovane su. Podaci su prikupljeni putem polustrukturiranih intervjua, dok su sociodemografska obilježja prikupljena putem kratkog upitnika. Za obradu podataka prikupljenih putem intervjua korištena je kvalitativna analiza sadržaja. Rezultati pokazuju kako iskustva sudionica istraživanja ukazuju na važnost osobnih karakteristika žene koja muca u svijetu rada i zapošljavanja, a koje sudionice smatraju povezanima s ishodima dobivanja posla ili napredovanja na poslu. U pogledu specifičnosti svakodnevnog života sudionice ističu postojanje straha od izrugivanja, straha od javnog govora, straha od negativnog utjecaja mucanja na posao kojim se bave. Podršku doživljavaju u privatnom životu kroz partnerski odnos, obitelji te $u$ akademskom i radnom okruženju. Zaključno rezultati daju uvid u specifična iskustva života odraslih žena koje mucaju, ukazujući na područja života u kojima doživljavaju osjećaj straha ili dodatne teškoće, a koja se mogu prevenirati razvojem adekvatnog sustava podrške za osobe koje mucaju.

Ključne riječi: žene, mucanje, podrška, privatni život, poslovni život, logopedska terapija

\section{UVOD}

Sposobnost komunikacije prožima svaki aspekt čovjekova života i razlikuje ga od drugih vrsta.
Izvorni znanstveni rad/Original research article UDK: 616.89-008.434-055.2 doi: https://doi.org/10.31299/hrri.57.1.5

\begin{abstract}
This study aimed to provide insights into the everyday life experiences of women who stutter based on data collected from six female participants. The average age of the participants was 29 years, they lived in an urban area, and had completed higher education studies. Data was collected through semi-structured interviews and a short questionnaire about socio-demographic factors. Qualitative content analysis was used to process the data collected in the interviews. The results indicated a correlation between the personal attributes of women who stutter and their experiences in the context of work and employment. These participants believed that personality traits were linked to outcomes related to employment or promotions. They also highlighted specific experiences involving the fear of being mocked, especially during public speaking, as well as the fear of their stutter having a negative impact on their professional activities. In their personal lives, the participants reported receiving support from their partners and families, as well as their colleagues in academic and professional environments. Our results offer an insight into the specific experiences of adult women who stutter, and reveal the circumstances that cause fear or additional difficulties among these women. These results must be taken into consideration while developing a support system for people who stutter.
\end{abstract}

Keywords: women, stuttering, support, personal life, professional life, speech therapy

\section{INTRODUCTION}

The ability to communicate is important for every aspect of the human existence. Speech rep- 
Čovjek najlakše ostvaruje komunikaciju putem govora, koji je dominantno i tipično sredstvo ljudske komunikacije. Govor je jedna od najbitnijih karakteristika koja nas čini ljudima, odnosno koja nas razlikuje od drugih vrsta. Omogućava nam izražavanje vlastitih potreba i želja, ostvarivanje temeljnih ljudskih prava, napredak $\mathrm{u}$ akademskom i poslovnom svijetu. Isto tako govor nam je nužan za izgradnju socijalnih odnosa, koji su, s obzirom na to da je čovjek socijalno biće, neophodni za njegov rast i razvoj. Oduzmemo li čovjeku mogućnost kvalitetnog govora, taj će čovjek biti, kako navodi Škarić (1988) "oštećen u ostvarenju sebe i svog dostojanstva”. Oduzimanje mogućnosti kvalitetnog govora označava postojanje govornih poremećaja i poteškoća (Škarić, 1988). Mucanje je, kao relativno čest i svima prepoznatljiv poremećaj, oduvijek zanimljiva tema znanstvenoj zajednici i široj javnosti. Možemo ga najjednostavnije opisati kao poremećaj tečnosti govora - pri čemu je tečnost ili fluentnost definirana kao govor s lakoćom, bez oklijevanja, ispravljanja i pogrešaka (Sardelić, Brestovci i Heđever, 2001). Ukoliko te tečnosti nema, čak i neiskusnom i nestručnom promatraču biti će jasno da se radi o mucanju. Ipak, ispod naizgled jednostavne slike ovog poremećaja krije se puno složenija stvarnost - koja osim govornih teškoća nerijetko uključuje i popratne, nevidljive simptome koji utječu na kvalitetu života osobe koja muca. Iz toga razloga možemo, iako se radi prvenstveno o govornim teškoćama, na mucanje gledati i kao na komunikacijski poremećaj (Yaruss, 2010) koji otežava svakodnevne interpersonalne odnose.

Mucanje je sindrom velikog broja manifestacija za koji ne postoji univerzalno prihvaćena definicija. Najčešće se povezuje s atipičnim govornim obrascem, no kao takvo uključuje i brojne druge komponente ljudskog života kao što su emocije, kognicija i socijalni aspekt (Yairi i Seery, 2015).

Unatoč brojnoj literaturi koja govori o mucanju i dalje su prisutni negativni stereotipi i netočna uvjerenja koja predstavljaju velike izazove s kojima se osobe koje mucaju moraju nositi, a što dugoročno može imati nepovoljan utjecaj na kvalitetu života te mogućnosti izbora i obavljanja zanimanja (Shapiro, 2011). Nang i suradnici (2018) u kvalitativnom istraživanju u kojem je sudjelovalo devet žena u dobi od 35 do 80 godina života dolaze do resents a direct, primary, and specific means of human communication. It is a distinctive property of human beings that distinguishes us from other species. It allows us to express needs and desires, affirm our basic human rights, and progress in education and work. Moreover, speech is paramount to establishing social relationships, which is indispensable for the growth and development of humans as social beings. Škarić (1988) believed that without effective speech/communication human beings will be "deprived of their self-actualisation and dignity".

A speech disorder or impediment designates the inability to speak effectively (Škarić, 1988). Stuttering is a relatively frequent and distinct impairment that has always intrigued the scientific community and the society. The basic definition of stuttering involves a disruption of speech fluency, where fluency refers to speaking effortlessly, without hesitation, corrections, or mistakes (Sardelić, Brestovci \& Heđever, 2001). In the absence of fluency, inexperienced and non-professional observers can easily identify stuttering. However, the seemingly simple signs of this disorder mask a more complex reality involving the covert manifestations of the impairment that affect the quality of life of people who stutter. Although it primarily causes speech impediments, stuttering is considered as a communication disorder (Yaruss, 2010) that can encumber everyday interactions. Finally, stuttering represents a syndrome with numerous manifestations that have not yet received a universally accepted definition. It denotes an atypical speech pattern which interferes with different aspects of human existence, including emotions, cognition, and social aspects (Yairi \& Seery, 2015).

Despite the extensive research conducted on stuttering, persistent stereotypes and misconceptions present considerable challenges for people who stutter, especially since, in the long run, it can affect quality of life and the opportunities available with respect to various professions (Shapiro, 2011). Based on qualitative research involving nine women aged 35 to 80 years, Nang et al. (2018) concluded that stuttering considerably influenced how women perceived themselves, their relationships, and their career potential. Given the sample considered, their study indicated lower self-assess- 
zaključka da mucanje ima značajan utjecaj na to kako žene vide sebe, svoje partnerske odnose, svoj potencijal u karijeri. Njihova studija na navedenom uzorku pokazala je kako su te žene imale lošiju procjenu kvalitete svojeg života i negativnu sliku o sebi kao ženi. Izrazile su negativan utjecaj mucanja na poslovnu karijeru i partnerske odnose. Boyle (2015) također ističe negativan utjecaj mucanja na kvalitetu života i na poslovnu ambiciju pojedinca koji muca. Klein i Hood (2004) proveli su studiju na uzorku od 232 osobe starije od 18 godina života, s ciljem istraživanja povezanosti mucanja s uspješnošću u profesionalnom kontekstu i kod napredovanja na poslu. Više od $70 \%$ sudionika smatra kako mucanje smanjuje šansu zapošljavanja i napredovanja na radnom mjestu. Više od 33\% sudionika smatra da mucanje ometa rad na poslu, dok ih je $20 \%$ odbilo zapošljavanje ili napredovanje na poslu zbog mucanja. U ovoj studiji pokazalo se kako muškarci mucanje doživljavaju težim u smislu teškoće koja ih ometa u poslovnom okruženju u odnosu na žene (Milton, 2013). Utjecaj mucanja na kvalitetu života kroz slabljenje socijalnih interakcija i pojačavanje socijalne anksioznosti predstavljaju u svojim istraživanjima i Klein i Hood (2004) te Plexico, Manning i Levitt (2009) i Aslihan (2011). Sve ove studije povlače paralelu između mucanja i toga kako osobe doživljavaju sebe, svoju društvenu mrežu, uspjeh u profesionalnom životu i ukupnu kvalitetu života.

\section{Etiologija i prevalencija mucanja}

Mucanje se kao poremećaj kroz povijest, od prvih kultura do danas, javljalo u svim dijelovima svijeta neovisno o dobi, rasi, socioekonomskom statusu ili spolu (Galić-Jušić, 2001). Iako uzrok mucanja do danas nije u potpunosti razjašnjen, ono je zasigurno produkt sinergije konstitucijskih i okolinskih faktora. Prve naznake mucanja javljaju se kod male djece za vrijeme njihova jezično-govornog razvoja. Nakon devete se godine incidencija mucanja znatno smanjuje, a kasnija prva pojava mucanja najčešće je kategorizirana kao psihogeno ili neurogeno mucanje. Po podacima Yairi i Seery (2015) incidencija (vjerojatnost pojave novih slučajeva) mucanja iznosi 5\% slučajeva, dok prevalencija (broj osoba koje mucaju u određenom trenutku) iznosi $1 \%$. ments of the quality of life and negative self-perceptions among women who stutter. The women also perceived the unfavourable effects of stuttering on their careers and relationships with partners. Boyle (2015) also established that stuttering can affect quality of life and career aspirations of individuals who stutter. A study by Klein \& Hood (2004) involving a sample of 232 individuals > 18 years of age examined the effects of stuttering on professional achievement and career advancement: more than $70 \%$ of the participants considered that stuttering lowered their chances of employment and professional advancement, while $>33 \%$ found that it affected their workplace performance; $20 \%$ reported that they were denied employment or promotion opportunities due to stuttering. Additionally, men considered speech impediments to be more disruptive in the workplace than women (Milton, 2013). Studies have also confirmed that stuttering affects quality of life by decreasing social interactions and increasing social anxiety (Klein \& Hood, 2004; Plexico, Manning \& Levitt, 2009; Aslihan, 2011). These studies also established links between stuttering and self-perception, perception of the social network, professional achievement, and overall quality of life.

\section{Aetiology and prevalence of stuttering}

Throughout history, from early cultures to the contemporary society, the stuttering disorder has been observed in different parts of the world, regardless of age, race, socioeconomic status, or sex (Galić-Jušić, 2001). Although the cause of stuttering has not been fully elucidated, it definitely ensues from an interplay of internal and external factors. The initial indication of stuttering generally coincides with the development of speech and language in early childhood. After the age of nine, the incidence of stuttering decreases considerably, and the subsequent first indication of stuttering is generally attributed to psychogenic or neurogenic stuttering. According to Yairi \& Seery (2015), the incidence of stuttering (the probability of occurrence of new cases) is about $5 \%$, while the prevalence (the number of people who stutter at a given time) is $1 \%$.

Among people who stutter, gender differences are observed across all age groups. These differenc- 
Razlike među spolovima vidljive su u svakoj dobnoj skupini među osobama koje mucaju. Također te su razlike i kvalitativne i kvantitativne. Muškarci češće mucaju od žena, dok žene češće imaju u užoj obitelji nekoga tko muca (Galić-Jušić, 2001). Žene su također otpornije na pojavu i razvoj mucanja te se u slučaju terapije bolje oporavljaju nego muškarci (Galić-Jušić, 2001). Iako je u najranijoj dobi pojavnost mucanja podjednaka i za djevojčice i za dječake, u odrasloj je dobi taj omjer mnogo drukčiji te govorimo o tri do četiri muškarca koji mucaju naspram jedne žene (Bloodstein i Ratner, 2008; Nang i sur., 2018).

\section{Simptomatologija mucanja}

Kada govorimo o simptomima mucanja, najčešće razlikujemo temeljne govorne simptome te popratne vegetativne pojave, uz karakteristične emocije i stavove osoba koje mucaju (Galić-Jušić, 2001; Guitar, 2014). U temeljne govorne simptome ubrajamo ponavljanja glasova i slogova te jednosložnih riječi, produživanja glasova te zastoje ili blokade koje se mogu događati na respiratornoj, fonatornoj ili artikulacijskoj razini. Nerijetke su i cirkumlokucije i produkcija riječi uz jaku tjelesnu napetost (APA, 2013.).

Negativne emocije i stavovi kao značajan dio simptomatologije mucanja tek su posljednjih godina uvedeni u opise teškoća osoba koje mucaju. To su skrivena ponašanja (Blomgren, 2010) koja, iako nisu vidljiva sugovorniku, uvelike utječu na kvalitetu života osobe koja muca. Emocije i reakcije koje su vidljive kod mucanja uključuju: strah, anksioznost, sram, neugodu, krivnju, bijes, ljutnju i frustraciju. Vrste emocija variraju s obzirom na vrijeme pojavljivanja netečnosti, pa tako osobe koje mucaju prije trenutka netečnosti doživljavaju emocije straha i anksioznosti, za vrijeme mucanja javlja se frustracija, a nakon netečnosti osoba doživljava osjećaje srama, neugode i ljutnje (Yairi i Seery, 2015). Strah je emocija koja osobe koje mucaju često usmjerava prema neprikladnim ili izbjegavajućim oblicima nošenja s mucanjem što ima negativne posljedice na kvalitetu života osoba koje mucaju (Plexico i sur., 2019). Plexico, Manning i Levitt (2009a, 2009b; prema Bleek i sur., 2012) otkrili su da izbjegavajuće strategije nošenja s mucanjem $\square$ nesudjelovanje u konverzaciji, socijalno povlačenje i suzbijanje negativnih emocija $\square$ es are both qualitative and quantitative in nature. Men stutter more often than women, whereas women are more likely to indicate a person who stutters in their close family (Galić-Jušić, 2001). Women are also less prone to begin and continue stuttering, and they definitely respond better to therapy than men (Galić-Jušić, 2001). Although the incidence of stuttering is similar among girls and boys in early childhood, this proportion shifts significantly in adulthood; studies have shown that there are at least three to four men who stutter for every woman who stutters (Bloodstein \& Ratner, 2008; Nang et al., 2018).

\section{Symptoms of stuttering}

The manifestations of stuttering generally pertain to core behaviours and related vegetative symptoms, along with distinctive emotions and attitudes of people who stutter (Galić-Jušić, 2001; Guitar, 2014). The behaviours associated with core speech comprise of repetitions of phonemes, syllables, and one-syllable words, prolongations of phonemes, as well as prolonged pauses or blocks, which may occur at respiratory, phonatory, or articulatory levels. Circumlocution and speech production accompanied by increased physical tension are also common (APA, 2013).

Although negative emotions and attitudes represent distinct symptoms of stuttering, they have only recently been added to the list of difficulties experienced by people who stutter. They represent covert behaviours that are often overlooked (Blomgren, 2010), but can considerably affect the quality of life of people who stutter. Visible emotions and reactions related to stuttering involve fear, anxiety, shame, embarrassment, guilt, fury, anger, and frustration. These emotions vary depending on the stages of the disfluency event: before disfluency, individuals who stutter experience fear and anxiety, followed by frustration during stuttering and subsequent feelings of shame, embarrassment, and anger (Yairi \& Seery, 2015). The feeling of fear frequently drives these individuals to choose ineffective coping mechanisms such as avoidance, which in turn affects their quality of life (Plexico et al., 2019). Plexico, Manning \& Levitt (2009a, 2009b; in Bleek et al., 2012) found that using avoidance as a coping strategy for stuttering (withdrawal from 
vodi do nesporazuma u komunikaciji, ograničenja u mogućnostima i općenito do smanjene kvalitete života. Mnoge osobe koje mucaju suočavaju se sa značajnim teškoćama kada žele govoriti (Packman i sur., 2004 prema Iverach i sur., 2011). Mucanje je poremećaj povezan s jakim negativnim emocionalnim reakcijama kao što je tjeskoba, koje pojačavaju negativne posljedice kao neuspješni pokušaji govorenja. Te posljedice mogu pratiti osjećaj srama i poniženja koji dovode do snižene motivacije (Craig i Tran, 2014). Iz tog razloga osobe koje mucaju često izbjegavaju govor, imaju poteškoće s društvenim okruženjem, teškoće u školi i u odnosima s drugima. Reakcije mogu biti jako kompleksne iz razloga što mnogi odrasli koji mucaju osjećaju strah i anksioznost tijekom cijelog života (Craig i Tran, 2014). Blomgren (2010) navodi da je osobama koje mucaju, a ne pate od anksioznosti, zajednički osjećaj srama, uznemirenosti, straha i frustracije.

\section{Vrste mucanja}

Novije podjele mucanje dijele ovaj poremećaj ovisno o dobi osobe koja muca, pa tako razlikujemo mucanje kod djece i kod odraslih. Ukoliko se radi o mucanju kod djeteta niske kronološke dobi, moguće je da se radi o normalnoj netečnosti $\square$ nerijetkoj pojavi za djecu tijekom intenzivnog govornog, jezičnog i motoričkog razvoja. U normalnoj netečnosti dijete ne pokazuje sekundarna ponašanja, nema svijest o svom mucanju, a u govoru ima do $10 \%$ netečnosti (Guitar, 2014). Razvojno mucanje također nastaje u dječjoj dobi, no slika samog mucanja i mogući ishodi drukčiji su nego kod normalne netečnosti. Razvojno mucanje, osim prisutne minimalno $3 \square 4$ netečnosti na uzorku od 100 slogova (Yairi i Seery, 2015), prepoznatljivo je i po početnim negativnim stavovima i svjesnosti o mucanju, koju prate i za mucanje karakteristična ponašanja (primjerice pokreti udova). Kad se govori o razvojnom mucanju, važno je naglasiti da ono obuhvaća i rano dječje mucanje u dobi od druge do pete godine, kao i mucanje djece starije predškolske dobi. Iako razvojno mucanje obuhvaća i mucanje djece školske dobi (od 6 do 12 godina), vrlo se često zasebno govori o mucanju djece školske dobi. Zadnjih se godina na temelju rezultata različitih istraživanja o mucanju uočava prihvaćenost i uporaba termina rano dječje mucanje, dječje mucanje $\mathrm{i} / \mathrm{ili}$ mucanje djece stari- conversation, social withdrawal, and suppression of distressing emotions) can lead to misunderstandings in communication, limitations in opportunities, and a decline in overall quality of life. Many individuals who stutter have experienced significant difficulties when they want to speak (Packman et al., 2004 in Iverach et al., 2011). Stuttering has been linked to severely negative emotional reactions, such as anxiety, that can be further exacerbated by the adverse effects of failed attempts to speak clearly. The accompanying feelings of shame and humiliation also tend to lower motivation (Craig \& Tran, 2014). According to Blomgren (2010), when they are not suffering from anxiety, individuals who stutter often feel shame, agitation, fear, and frustration.

\section{Types of stuttering}

Contemporary definitions of stuttering consider the age of individuals who stutter, thus distinguishing stuttering in children from stuttering in adults. In early childhood, stuttering may involve normal disfluency, a common occurrence for children during intensive speech, linguistic, and motoric development. In the case of normal disfluency, children do not display secondary behaviours, they are unaware of stuttering, and their speech may comprise up to $10 \%$ of disfluencies (Guitar, 2014). Developmental stuttering also appears in childhood with manifestations and outcomes that are different from normal disfluency. Developmental stuttering is diagnosed when a minimum of three to four disfluencies occur per 100 syllables (Yairi $\&$ Seery, 2015), accompanied by initial negative attitudes, awareness of stuttering, and symptomatic behaviours such as limb movement. Developmental stuttering notably encompasses early childhood stuttering from the age of two to five and stuttering in older pre-school children. Although developmental stuttering is associated with stuttering in school-aged children (6-12 years), this group is often discussed separately. Based on relevant research studies on stuttering, the terms 'early childhood stuttering', 'childhood stuttering' and/or 'stuttering in older pre-school or school-aged children' have recently become more accepted, and are preferred over the term 'developmental stuttering'. According to recent estimates, $3.46 \%$ of children 
je predškolske ili školske dobi umjesto razvojnog mucanja. Prema novijim istraživanjima procjenjuje se da u predškolskoj populaciji 3,46\% djece muca, a u školskoj populaciji 0,83\% (Yairi i Seery, 2015). Iako se u djece mogu javiti netečnosti kao rezultat nekog neurološkog oštećenja, one su vrlo rijetke o čemu svjedoči i malen broj takvih slučajeva zabilježenih u literaturi (Nass, Schreter, Heier, 1994; prema Theys i sur., 2011; Yeoh, Lind i Law, 2006; prema Theys i sur., 2009; Theys i sur., 2009).

Kod odraslih se vrste mucanja ponešto razlikuju od onih u dječjoj dobi. Ukoliko se razvojno mucanje nastavilo kroz ostatak života osobe, govorimo o razvojno perzistentnom mucanju. Sva primarna govorna ponašanja (ponavljanja, produživanja i blokade) i dalje su prisutna te ih je osoba svjesna, a nerijetka su i sekundarna ponašanja (pokreti glave, lica i ekstremiteta te negovorni zvukovi). Osim ovih naoko vidljivih simptoma osoba s razvojno perzistentnim mucanjem doživljava i skrivene simptome mucanja - sram, anksioznost, nesigurnost, izbjegavajuća ponašanja. Novostečene emotivne komponente mucanja u odrasloj dobi dodatno otežavaju sliku poremećaja, budući da se osoba počinje promatrati kroz prizmu svojih teškoća te se zatvarati na socijalnom i emocionalnom planu.

Osim razvojno perzistentnog mucanja koje je kod odrasle osobe koja muca (u daljnjem tekstu OKM) prisutno još od djetinjstva, mucanje se prvi put može javiti i u odrasloj dobi i tada govorimo o stečenom mucanju čiji početak nije razvojnog podrijetla. S obzirom na etiologiju stečenog mucanja, razlikuje se neurogeno mucanje, psihogeno mucanje i mucanje uzrokovano lijekovima (Van Borsel, 2014). Najčešći oblik stečenog mucanja u odrasloj dobi jest neurogeno mucanje (Van Borsel i Taillieu, 2001). Potrebno je naglasiti kako se ponekad termin stečeno mucanje pogrešno koristi kao sinonim za neurogeno mucanje (Van Borsel, 2014). Neurogeno mucanje je stečeni poremećaj tečnosti govora koji obično pogađa odrasle osobe uslijed neurološkog oštećenja (Theys i sur., 2008; Ward, 2010). Kao najčešći uzroci neurogenog mucanja navode se moždani udar, traumatska oštećenja mozga, neurodegenerativne bolesti, tumori i korištenje narkotika (Manning, 2010; Theys i sur., 2008; Bloodstein i Bernstein Ratner, 2008). Podaci o etiologiji navode na zaključak kako se neurogeno mucanje ne može povezati isključivo s oštećenjem in preschool and $0.83 \%$ of school-aged children stutter (Yairi \& Seery, 2015). Although speech disfluencies in children may occur as a consequence of neurological trauma, this is quite uncommon and rarely discussed in published literature (Nass, Schreter, Heier, 1994 in Theys et al., 2011; Yeoh, Lind \& Law, 2006 in Theys et al., 2009; Theys et al., 2009).

The types of stuttering in adulthood are different from stuttering in childhood. Persistent developmental stuttering occurs as a result of developmental stuttering that has continued over different stages of life. Adults who stutter display all core behaviours (repetitions, prolongations, or blocks), and are typically aware of stuttering. They also display secondary behaviours such as head, face, and limb movements, as well as inarticulate sounds. Besides the visible signs, a person with persistent developmental stuttering also experiences covert symptoms of stuttering, including shame, anxiety, insecurity, and avoidance behaviours. New emotional aspects of stuttering in adulthood further aggravate these manifestations as the person begins to identify with the disorder and withdraws socially and emotionally.

Besides persistent developmental stuttering, which has accompanied adults who stutter since childhood, stuttering can also begin during adulthood without any particular developmental basis, denoting an 'acquired stuttering'. Considering the aetiology of acquired stuttering, Van Borsel (2014) reported different types including neurogenic, psychogenic, and drug-induced stuttering. Neurogenic acquired stuttering is the most common type observed during adulthood (Van Borsel $\&$ Taillieu, 2001). Sometimes, the term 'acquired stuttering' is misused as a synonym of 'neurogenic stuttering' (Van Borsel, 2014).

Neurogenic stuttering represents an acquired speech disfluency disorder that generally affects adults who have suffered a previous neurological trauma (Theys et al., 2008; Ward, 2010). Common causes of neurogenic stuttering involve stroke, brain trauma, neurodegenerative diseases, tumours, and narcotic abuse (Manning, 2010; Theys et al., 2008; Bloodstein \& Bernstein Ratner, 2008). Aetiology data indicates that neurogenic stuttering cannot be exclusively related to trauma on a specific part 
određenog dijela mozga već mogu biti zahvaćene različite neurološke strukture koje su dio neuralne mreže za proizvodnju tečnog govora (Van Borsel i Taillieu, 2001; Theys i sur., 2008; Ward, 2010). Psihogeno se mucanje odnosi na iznenadni početak mucanja u odrasloj dobi kojem prethodi značajan traumatski događaj (Ward, 2010). Ono se pojavljuje uslijed nekog stresnog događaja, velikih konflikata ili duljih pritisaka kojima je osoba izložena (Mahr, 1990, prema Galić-Jušić, 2001). Uzroci variraju ali se svi povezuju s visokom razinom stresa $\mathrm{i} / \mathrm{ili}$ anksioznosti. Iako se radi o mucanju psihološke (emocionalne) naravi, važno je istaknuti da je kod ovakvog oblika mucanja, uz psihoterapijske postupke nužna i uključenost logopeda u terapiji. Mucanje uzrokovano lijekovima (eng. drug-induced stuttering) podrazumijeva netečnosti koje su nuspojava korištenja različitih lijekova (Van Borsel, 2014). Mucanje uzrokovano lijekovima razlikuje se po pitanju uzro$\mathrm{ka}$, dijagnostike i primjerene intervencije. Za razliku od neurogenog mucanja uzrok ove vrste mucanja može se otkloniti. Stoga postoje dobri argumenti koji idu u prilog stajalištu da je mucanje uzrokovano lijekovima zasebna kategorija stečenog mucanja (Andrijolić i Leko Krhen, 2016; Van Borsel, 2014).

Može se reći da odrasli koji mucaju predstavljaju manji broj onih koji su ikad mucali. Njihova perzistentnost mucanja najvjerojatnije je odraz jednog šireg poremećaja. Ustvari, genetika je važan čimbenik koji je u podlozi i spontanog oporavka i kroničnog mucanja (Ambrose i sur. 1997).

\section{Mucanje kod adolescenata i mucanje u odrasloj dobi}

Klinička slika mucanja kod adolescenata i odraslih osoba po mnogočemu je različita od mucanja u djetinjstvu. Većinom se radi o težem obliku mucanja koje je popraćeno brojnim sekundarnim ponašanjima, poput izbjegavanja određenih riječi ili situacija (Guitar, 2014). Budući da se radi o uznapredovalom (razvojno perzistentnom) mucanju, koje je do rane odrasle dobi sada problem osobe koja muca veći dio života, osoba koja muca razvija poseban stav prema svom mucanju. Uznapredovalo mucanje (Galić-Jušić, 2001) definira se kao skup govornih simptoma, stavova i osjećaja oko vlastitog govora koji zbog svoje dugotrajnosti postaju dio osobnosti osobe koja muca. Za odrasle osobe koje mucaju to više nije samo govor- of the brain, but different neurological structures that form a part of the neural network for fluent speech production might be affected (Van Borsel $\&$ Taillieu, 2001; Theys et al., 2008; Ward, 2010). Psychogenic stuttering refers to the sudden onset of stuttering in adults; it is typically preceded by a severe traumatic event (Ward, 2010). It might occur in the aftermath of a stressful event, an exceptional conflict, or extended exposure to pressure (Mahr, 1990, in Galić-Jušić, 2001). Although causes may vary, they are all linked to high levels of stress and/ or anxiety. Since this type of stuttering has a psychological (emotional) background, it is beneficial to include speech therapy into the treatment program along with psychotherapy. Finally, drug-induced stuttering denotes the presence of speech disfluencies as a side effect of drug therapies (Van Borsel, 2014). Drug-induced stuttering has various causes, diagnostic methods, and appropriate interventions. Contrary to the origin of neurogenic stuttering, the causes of drug-induced stuttering can be removed. Therefore, it could very well be argued that drug-induced stuttering belongs to a distinct category of acquired stuttering (Andrijolić \& Leko Krhen, 2016; Van Borsel, 2014).

It is important to note that adults who stutter form a smaller proportion of all individuals who stutter. In their case, the persistency of stuttering most likely reflects a broader disorder. In fact, genetics seem to be a significant predictor of spontaneous recovery and chronic stuttering (Ambrose et al. 1997).

\section{Stuttering in adolescence and adulthood}

The clinical manifestations of stuttering in adolescence and adulthood significantly differ from stuttering in childhood. Adults typically experience severe forms of stuttering associated with different secondary behaviours, such as avoiding certain words or situations (Guitar, 2014). In cases where advanced (persistent developmental) stuttering has accompanied young adults for most of their lives, they typically develop a specific attitude towards stuttering. Advanced stuttering (Galić-Jušić, 2001) represents an ensemble of symptoms, attitudes, and feelings about one's speaking abilities that have integrated into the personality of these individuals, especially given their long-term presence. 
na teškoća, već i velik emocionalni teret koji označava skrivenu manifestaciju mucanja. Iako istraživanja pokazuju da emocije imaju manju ulogu u uzroku mucanja, one mogu imati važnu ulogu u osobnom prilagođavanju na mucanje i mogu značajno otežati pokušaj osobe koja muca da promijeni svoj govor (Yairi i Seery, 2015). Mucanje je potencijalno socijalno-komunikacijski problem koji ima negativan utjecaj na mentalno i emocionalno zdravlje te druge aspekte života (Kasbi i sur., 2015). Kod većine je osoba koje mucaju sudjelovanje u svakodnevnim aktivnostima narušeno, a u nekim slučajevima mucanje uzrokuje probleme i u komunikaciji tijekom govornih aktivnosti koje uključuju razgovor preko telefona ili razgovor pred drugim ljudima. Najčešće će se komunikacijski problemi pojaviti u širokom obujmu aktivnosti u školi, kod kuće ili na poslu (Kasbi i sur., 2015). Istraživanja o kvaliteti života osoba koje mucaju tek su početkom ovog tisućljeća doživjela svoj začetak (Klompas i Ross, 2004). Prema dosadašnjim istraživanjima mucanje ima potencijalno negativan utjecaj na emocionalno i mentalno zdravlje osoba koje mucaju, posebice u odraslih (Bloodstein \& Bernstein Ratner, 2008; Craig \& Tran, 2006). Odrasli koju mucaju također su rizičniji za narušeno mentalno i socijalno zdravlje te za doživljavanje povećane razine anksioznosti, o čemu će više riječi biti kasnije. Istraživanja su isto tako pokazala da odrasle osobe koje mucaju mogu imati teškoća sa zapošljavanjem zbog mucanja (Bloodstein \& Bernstein Ratner, 2008). Još jedan od uzroka teškoća jest povratak na prvotno stanje nakon terapije, što je čest izvor teškoća za odrasle osobe koje mucaju. Sukladno tomu odrasle osobe koje mucaju stvaraju i negativne stereotipe o samima sebi (Craig i sur., 2003). Važno je naglasiti da mucanje često može biti povezano s nižom kvalitetom života što možemo promatrati kroz razne domene života kao što su društveni život i emocionalno funkcioniranje (Craig i sur., 2009 prema Blumgart i sur., 2014). Teškoće kod proizvodnje govora, loša školska postignuća i odabir zanimanja, socijalni stereotipi i izbjegavanje situacija povezani su i njihovo zajedničko djelovanje može dovesti do socijalne anksioznosti kod osoba koje mucaju (Klarin, Leko Krhen, Jelčić Jakšić, 2018). Poremećaj socijalne anksioznosti, koji se ponekad naziva i socijalnom fobijom, poremećaj je u kojem osoba osjeća ekstremnu i intenzivnu anksioznost pri iščekivanju mogućeg sramoćenja i nelagode u socijalnim situacijama te vjeruje da će ga drugi osuđivati
For adults, stuttering is no longer a mere speech impairment; one of its covert manifestations is that it represents an emotional burden. Although studies have shown that emotions assume a minor role with respect to the causes of stuttering, they can significantly affect personal adjustment to stuttering and significantly impede the attempts made by individuals who stutter to amend their speech (Yairi $\&$ Seery, 2015). Stuttering may also present social and communication issues with negative repercussions for mental and emotional health, as well as other aspects of life (Kasbi et al., 2015). Stuttering affects participation in everyday activities for most people or causes difficulties in communication and speaking, including telephone conversations and speaking in front of other people. Communication issues occur in a broad range of activities at school, home, or work (Kasbi et al., 2015). Unfortunately, research on the quality of life of individuals who stutter emerged only at the beginning of our millennium (Klompas \& Ross, 2004). Until now, research studies have detected possible negative effects of stuttering on emotional and mental health of individuals who stutter, especially adults (Bloodstein \& Bernstein Ratner, 2008; Craig \& Tran, 2006). Adults who stutter are at greater risk of mental health and social deterioration, and have higher levels of anxiety. Studies have also indicated that adults encountered barriers to employment because of their stuttering (Bloodstein \& Bernstein Ratner, 2008). Relapse after treatment posed another considerable challenge for adults who stuttered. As a consequence of all these challenges, they ended up developing harmful stereotypes about themselves (Craig et al., 2003).

Stuttering is frequently linked to lower quality of life in different domains, including social life and emotional functioning (Craig et al., 2009 in Blumgart et al., 2014). Difficulties in speech production, fewer scholastic achievements and occupational choices, social stereotypes and avoidance are all interconnected; moreover, their interplay can cause social anxiety among individuals who stutter (Klarin, Leko Krhen, Jelčić Jakšić, 2018). The social anxiety disorder, sometimes called social phobia, can result in a conviction of being judged by others and feelings of exceptional and intense anxiety when anticipating potential embarrassment 
(Schneier, 2003). Zbog tog straha mnoge anksiozne osobe izbjegavaju događaje koji bi mogli biti stresni, poput javnih govora, društvenih događanja ili sastanaka (Craig i Tran, 2006). Socijalna anksioznost češća je kod osoba mlađih od 60 godina, a procjenjuje se da je kod opće populacije prisutna u omjeru između $7 \%$ i $12 \%$ (Kessler, 2005). Kao i ostali psihički poremećaji socijalna anksioznost negativno utječe na svakodnevno funkcioniranje i kvalitetu života. Ima utjecaj na funkcioniranje i izvedbu u različitim situacijama (Erzati-Vinacour i Levin, 2004), poput kvalitete rada na poslu ili mogućnosti interakcija u društvu. Budući da postoje brojne dodirne točke mucanja i socijalne anksioznosti, poput nelagode i straha u socijalnim situacijama te izbjegavanja druženja s drugima, nameću se pitanja njihove moguće povezanosti. Osoba koja muca može osjećati socijalnu anksioznost jednakog intenziteta kao osoba s dijagnozom poremećaja socijalne anksioznosti (Craig i Tran, 2006) - i iako je ta fobija vjerojatno direktna posljedica mucanja, ona svejedno zahtjeva tretman i pomoć.

Još tijekom predškolskih dana (Ezrati-Vinacour i sur., 2001; Langevin i sur., 2009 prema Iverach i sur., 2011) mogu se pojaviti teškoće koje onda mogu utjecati na socijalno i emocionalno funkcioniranje, odnose, kvalitetu života i mentalno zdravlje. Negativne posljedice mogu se nastaviti tijekom cije$\log$ životnog vijeka. Uključuju negativne reakcije slušatelja, negativne stereotipe, nasilničko ponašanje i zadirkivanje, socijalnu izolaciju, teškoće održavanja odnosa, obrazovne i radne neuspjehe te strah od govorenja u javnosti (Turnbaugh i sur., 1979; Davis i sur., 2002; Cream i sur., 2003; Blood i Blood, 2007; O'Brian i sur., 2011 prema Iverach i sur., 2011). Socijalne teškoće s kojima se suočava osoba koja muca vode do povećane anskioznosti što predstavlja razumnu reakciju. Kao rezultat tjeskoba u komunikacijskim ili socijalnim situacijama može se smatrati predvidljivim ishodom posljedica neuspješne komunikacije koji osoba koja muca proživljava tijekom cijelog života (Ingham, 1984; Miller i Watson, 1992; Bloodstein, 1995 prema Iverach i sur., 2011). Velik broj istraživanja pokazao je da osobe koje mucaju imaju visoku razinu socijalne anksioznosti, s tim da je anksioznost prvenstveno posljedica, a ne uzrok mucanja. Promatranje povratnih informacija o negativnim ili anksioznim reakcijama na mucanje uvjerilo je teoretičare kako postoji evidentna uzroč- or unease during social interactions (Schneier, 2003). Due to such fears, many anxious individual tend to avoid potentially stressful circumstances, such as public speaking, social events, or meetings (Craig \& Tran, 2006). Social anxiety is more frequent in individuals $<60$ years of age, while its prevalence in the general population is estimated at $7-12 \%$ (Kessler, 2005). Like other psychological disorders, social anxiety adversely influences daily functioning and quality of life. It has notable effects on functioning and performance in various situations (Erzati-Vinacour \& Levin, 2004), including professional performance or social interactions. Given the complex interplay between stuttering and social anxiety, unease and fear during social interactions, and social avoidance, their interconnectedness seems inevitable. The intensity of social anxiety may even be comparable between individuals who stutter and those diagnosed with social anxiety disorder (Craig \& Tran, 2006). Therefore, even if the phobia occurs as a result of stuttering, it definitely requires treatment and support.

Initial difficulties may appear as early as in preschool (Ezrati-Vinacour et al., 2001; Langevin et al., 2009 in Iverach et al., 2011), affecting social and emotional functioning, relationships, quality of life, and mental health. Unfavourable effects may continue over the course of the entire lifetime. They involve disapproving reactions from interlocutors, harmful stereotypes, violent behaviour or teasing, social isolation, difficulties in maintaining relationships, fewer scholastic or professional achievements, and fear of public speaking (Turnbaugh et al., 1979; Davis et al., 2002; Cream et al., 2003; Blood \& Blood, 2007; O'Brian et al., 2011 in Iverach et al., 2011). Social difficulties faced by individuals who stutter may lead to higher anxiety, which seems like a reasonable reaction. Therefore, during social occasions or those involving speaking, anxiety seems to be an expected outcome among individuals who stutter since they may face detrimental effects on communication throughout their entire lives (Ingham, 1984; Miller \& Watson, 1992; Bloodstein, 1995 in Iverach et al., 2011). Several studies have demonstrated that individuals who stutter experience high levels of social anxiety, primarily as a consequence, and not as the cause of stuttering. Moreover, based on feedback analysis 
no-posljedična veza između mucanja i anksioznosti. Povezanost mucanja i anksioznosti jedan je od razloga zašto se terapiji mucanja u odrasloj dobi pristupa na najobuhvatniji način - kombinacijom logopedske terapije i psihoterapije. Do odrasle dobi većina odraslih osoba počela se definirati kroz svoje mucanje, na temelju njega stvorili su sliku sebe i sliku drugih ljudi te često razvili anksioznost ili izbjegavajuća ponašanja (Galić-Jušić, 2001). Terapija u odrasloj dobi također je specifičan proces - budući da osoba sada mora preuzeti vlastitu odgovornost i pokazati snagu volje, a često se i toliko saživjela sa svojim mucanjem, da odbija novi način govora naučen terapijom (Galić-Jušić 2001). Upravo se prisutnost socijalne anksioznosti kod odraslih koji mucaju smatra jednim od mogućih razloga zašto govorno restrukturiranje, koje je jedna od najstarijih terapijskih tehnika u mucanju, nema trajan učinak na mucanje (Craig \& Hancock, 1995). Logopedska terapija često može biti teža kod odraslih osoba koje mucaju jer su kroz život vjerojatno već prošle kroz neku vrstu terapije (Yairi i Seery, 2015) koja je na njih ostavila negativan dojam te mogu pokazivati otpor $\mathrm{u}$ terapiji zbog nepovjerenja ili nedostatka motivacije.

Kao što je poznato terapije su mucanja brojne, većinom svoj temelj imaju u brojnim teorijama mucanja, te se razlikuju po ciljevima. Osim terapijskih tehnika koje imaju za cilj povećanje tečnosti govora i modifikaciju mucanja, gotovo jednaku važnost zauzima usmjerenost na bihevioralne, psihološke i emocionalne faktore koje mucanje sa sobom nosi, a upravo kognitivno-bihevioralna terapija predstavlja pristup koji sve navedeno objedinjuje. Kognitivno-bihevioralna terapija široko je prepoznata i primjenjiva intervencija koja je razvijena u polju kliničke psihologije i psihijatrije, pomaže ljudima u istraživanju utjecaja misli, osjećaja i fizioloških reakcija na njihovo ponašanje i pomaže im u modifikaciji tih utjecaja i samog ponašanja (Menzies i sur., 2009). Korisnost kognitivno-bihevioralne terapije dokazana je kod djece $\mathrm{i}$ adolescenata s poteškoćama i poremećajima u mentalnom zdravlju (Kelman i Wheeler, 2015). S obzirom na to da djeca koja mucaju mogu razviti negativne reakcije prema svojem govoru već od rane dobi, te posljedično kasnije i socijalnu anksioznost, kognitivno-bihevioralna terapija može koristiti i u terapiji mucanja. Štoviše, ovakav tip terapije jako of the negative and anxious reactions to stuttering, theoreticians established a distinct interconnection between stuttering and anxiety. This makes a strong argument for an integrated approach that combines speech therapy with psychotherapy to treat adults who stutter. The integrated approach is advisable since most of these individuals have already constructed their identity around stuttering as they reach adulthood; their perception of self and others is also associated with anxiety and avoidance behaviours (Galić-Jušić, 2001). Therapy for adults is a specific process - it requires taking responsibility and demonstrating determination in spite of the fact that stuttering is a distinct part of their identity; this may push adults to refuse new speaking techniques proposed by their therapists (Galić-Jušić 2001). The presence of social anxiety in adults who stutter might explain why speech restructuring, as a long-standing technique in speech therapy, has not been effective in the long run (Craig \& Hancock, 1995). Speech therapy is frequently more challenging for adults who stutter due to the negative experiences associated with previous treatments (Yairi \& Seery, 2015); this can potentially lead to resistance to therapy and lack of trust or motivation.

There are many well-known approaches to treat stuttering based on different theories and goals. Along with techniques for increasing speech fluency and modifying stuttering, it is important to pay equal attention to behavioural, psychological, and emotional factors associated with stuttering. Cognitive behavioural therapy (CBT) can offer a comprehensive approach after considering all these factors. CBT represents a widely recognized and broadly applicable intervention, elaborated in the clinical psychology and psychiatry fields; this technique supports individuals by examining the impact of thoughts, feelings, and physiological reactions to their behaviour and helps them modify the impact of stuttering and associated behaviours (Menzies et al., 2009). Cognitive behavioural therapy has proven effective for children and adolescents with mental health difficulties and disorders (Kelman $\&$ Wheeler, 2015). As children who stutter may suffer adverse reactions to their speech, and consequently, social anxiety, at an early age, CBT may prove equally effective for speech therapy. CBT 
je važan i potreban kada je već prisutan anksiozni poremećaj kod osoba koje mucaju, jer njegova prisutnost često negativno utječe, odnosno smanjuje pozitivne rezultate terapije mucanja usmjerene na reduciranje netečnosti (Iverach i sur., 2009).

\section{CILJ ISTRAŽIVANJA I ISTRAŽIVAČKA PITANJA}

Cilj ovog rada bio je istražiti doživljaje žena koje mucaju vezano uz njihov privatni život, područje rada i zapošljavanja te logopedske terapije.

Slijedom navedenog cilja postavljena su sljedeća istraživačka pitanja:

1. Kakva su iskustva privatnog života iz perspektive žena koje mucaju?

2. Kakva su iskustva iz područja rada i zapošljavanja žena koje mucaju?

3. Kako se doživljavaju aspekti logopedske terapije iz perspektive žena koje mucaju?

\section{METODOLOGIJA ISTRAŽIVANJA}

\section{Sudionici istraživanja}

Sudionici u ovom istraživanju odabrani su prigodnim uzorkom, a ukupno je sudjelovalo šest osoba ženskog spola. Sudionici su prikupljeni na način da se na Portalu mucanje, stranici na Facebooku koja okuplja osobe koje mucaju, objavio poziv za sudjelovanje u istraživanju, zajedno sa svim relevantnim podacima o istraživanju i kontaktima istraživača. Kriteriji za sudjelovanje $\mathrm{u}$ istraživanju bili su da je osoba punoljetna, da živi u Hrvatskoj i da muca u vremenskom razdoblju duljem od pet godina. Sve sudionice žive u urbanim naseljima većim od 100000 stanovnika te imaju visoki stupanj obrazovanja. Prosječna dob sudionica iznosi 29 godina. Zanimanja sudionica jesu: prodavačica, tajnica, novinarka, menadžerica i geodetkinja.

\section{Metoda i postupak prikupljanja i analize podataka}

Prikupljanje podataka provedeno je kroz upitnik o sociodemografskim podacima kojim su prikupljene osnove informacije od sudionica istraživanja (godine života, bračno stanje, profesija, informacije is particularly beneficial for individuals who stutter who have already developed anxiety disorders since these individuals cannot be treated effectively using stuttering treatment that help reduce disfluencies (Iverach et al., 2009).

\section{RESEARCH AIM AND RESEARCH QUESTIONS}

This study aimed to examine the experiences of women who stutter in terms of their personal lives, work, employment, and speech therapy.

The following research questions were addressed:

1. What are the personal life experiences of women who stutter?

2. What are the work and employment experiences of women who stutter?

3. How do women who stutter perceive different aspects of speech therapy?

\section{METHODOLOGY}

\section{Research participants}

Convenience sampling was conducted to select research participants for this study. To recruit participants, an advertisement to take part in a research study was posted on the "Stuttering portal" Facebook page for people who stutter; this advertisement included relevant information on the proposed research study and the e-mail address of the researcher. The criteria for participation stated that respondents should have reached the age of majority, live in Croatia, and have stuttered for over five years. A total of six female participants with an average age of 29 years were selected. All participants lived in urban areas with over 100,000 residents and had completed higher education studies. These women worked in sales, as a secretary, journalist, manager, and geodetic engineer.

\section{Data collection and analysis}

We collected data based on a questionnaire about socio-demographic factors, including age, marital status, profession, and information on stuttering (beginning, intensity etc.), as well as an interview protocol with 11 open questions based 
vezane uz mucanje: početak, intenzitet i slično) i protokol za intervju koji je sadržavao 11 otvorenih pitanja (postavljena pitanja slijede cilj istraživanja i u nastavku predstavljena tri istraživačka pitanja). Upitnik je dan sudionicama na ispunjavanje prije provođenja intervjua. Istraživanje je provedeno u Gradu Zagrebu tijekom svibnja, lipnja i srpnja 2019. Prilikom prikupljanja podataka i provođenja istraživanja strogo su se poštivala etička načela u znanstveno-istraživačkom radu. Dobiveni podaci obrađeni su kvalitativnom analizom sadržaja. Postupak je započeo višestrukim čitanjem transkripta od strane tri istraživača, odvajanjem odgovora relevantnih za cilj istraživanja $i$ istraživačka pitanja te sumiranjem individualnih analiza u završnu cjelinu. U cilju zaštite povjerljivosti sudionika istraživanja izjave sudionica označene su rednim brojevima od 1 do 6 .

\section{REZULTATI I RASPRAVA}

Obradom podataka dobivenih iz sociodemografskog upitnika kod 50\% sudionica mucanje je počelo prije 6 . godine života, a kod druge polovine između 6. i 10. godine. U pitanju o njihovoj subjektivnoj procjeni jakosti mucanja polovica sudionica svoje mucanje na njegovu početku procjenjuje kao umjereno, dok polovica navodi kako je ono bilo jako. Napominjemo da je riječ o subjektivnim procjenama sudionica istraživanja, kojima smo dobili informaciju kako one doživljavaju jakost svog mucanja. Procjenom intenziteta trenutačnog mucanja vidljiva je promjena $u$ intenzitetu mucanja tijekom vremena jer trećina sudionica svoje mucanje danas procjenjuje kao umjereno, dok ga dvije trećine sudionica procjenjuje kao vrlo blago ili blago. Iz pitanja o područjima života u kojima osoba ima najviše problema s mucanjem vidljivo je da su područja s najviše teškoća u govoru tijekom života: odnosi s autoritetima tijekom djetinjstva i danas, čitanje, predstavljanje i javni nastup. Osim toga druga područja u kojima sudionice procjenjuju postojanje poteškoća jesu odnos s obitelji, odnosi s prijateljima, odnos s partnerom i telefoniranje. U upitniku je postavljeno i pitanje o vrstama logopedske terapije koje su sudionice potencijalno pohađale, te je otkriveno da su tri sudionice pohađale logopedsku terapiju tijekom osnovne škole, terapiju VaLMod dvije ispitanice, dok su dvije ispitanice on the aim of this study and three research questions listed above. The participants filled out the questionnaire before the interviews. The interviews were conducted in the city of Zagreb between May and July, 2019. The data collection process and the study design was developed in compliance with the standard ethical principles of scientific research. Qualitative content analysis was used to process the data. This process involved multiple reviews of the transcripts by three researchers, identification of answers relevant to the research aims and research questions, as well as the summarization of individual analyses into the final analysis. Participant statements were coded using ordinal numbers from 1 to 6 to ensure the confidentiality of data provided by the participants.

\section{RESULTS AND DISCUSSION}

Based on the data from the questionnaire about socio-demographic factors, we found that half of the participants started stuttering before the age of six, and the other half between the ages of six and ten. When asked to appraise the severity of stuttering in the beginning, half of participants assessed their stuttering as moderate, whereas the other half perceived their stuttering as severe. The participants' subjective assessment provided insight into their perception of the severity of stuttering. It is important to note that their appraisal of the current intensity of stuttering indicated a perceived shift in the severity of stuttering over time: a third of the participants said their present stuttering was moderate, while the other two-thirds assessed it as very mild or mild. A question related to the situations that posed the greatest challenges in view of stuttering so far revealed that speech difficulties mostly occurred in relation to authority during childhood; challenging situations at present included reading, presentations, and public speaking. The participants also reported difficulties with respect to family relationships, friendships, relationships with partners, and telephone conversations. In response to the question about the types of speech therapy that the participants might have attended, three participants said that they had attended speech therapy in primary school, two participants had attended VaLMod therapy (specific speech therapy of stut- 
Tablica 1. Kakva su iskustva privatnog života iz perspektive žena koje mucaju? / Table 1. What are the personal life experiences of women who stutter?

\begin{tabular}{|l|l|}
\hline TOPICS & CATEGORIES \\
\hline \multirow{2}{*}{ Support from parents } & Calming \\
\cline { 2 - 2 } & Support and assistance \\
\hline \multirow{2}{*}{ Support from friends } & Understanding \\
\cline { 2 - 2 } & Conversation \\
\hline \multirow{2}{*}{ Support from partners } & Patience \\
\cline { 2 - 2 } & Inquiry \\
\hline \multirow{2}{*}{ Lack of support from parents } & Encouragement \\
\cline { 2 - 2 } & Positive attitude \\
\hline Lack of support from friends & Disregard \\
\cline { 2 - 2 } & Avoiding conversation \\
\hline Lack of support from partners & Disregard \\
\cline { 2 - 2 } & Negative attitude \\
\hline & Frustration \\
\cline { 2 - 2 } & Annoyance \\
\hline
\end{tabular}

izjavile da uopće nisu pohađale logopedsku terapiju tijekom života.

Rezultati prikupljeni putem polustrukturiranog intervjua prikazani su kroz tri tablice koje prate postavljena istraživačka pitanja.

Sudionice u području odnosa s primarnom obitelji s obzirom na mucanje iskazuju pozitivna iskustva pružanje podrške od strane roditelja: “... samo mi kažu ono daj se malo smiri...” (3); “... oni su me smirivali kad bi baš ono mi bilo teško pričat'...'; “... ako bi ja negdje htjela poć' ili probat' uvijek će me poduprijet'...”. Podršku koju dobivaju od braće i sestara opisuju kao razumijevanje i razgovor: “... nikad mi nisu ništa rekle za to kad mi je trebalo vremena, znači uvijek su bile strpljive..." (2) "Sa sestrom i bratom sam dosta pričala... otvoreno pričamo..." (4).

Neke sudionice u manjoj mjeri govore o negativnim iskustvima doživljenim od strane roditelja, koja opisuju kao izostanak podrške, koji se očituje kroz umanjivanje značaja tegoba koje imaju ili kroz izbjegavanje razgovora o mucanju: “... oni i dalje misle da je to meni samo u glavi, da sam ja to nekako sve prenapuhala..." (4); "Izbjegavali su temu..." (5)

Klompas i Ross (2004) u području utjecaja mucanja sudionika na njihov odnos s roditeljima i braćom i sestrama iskazuju nešto negativnija iskustva u ovom području te navode da su roditelji prema njima pokazivali nestrpljivost, manjak tering in the town of Varaždin) stated that they had never attended speech therapy.

The results of the semi-structured interviews are presented in three tables corresponding to each research questions.

Considering the relationship with their close family (Table 1), participants expressed positive experiences regarding stuttering (support from parents): '...they tell me, come on, calm down a bit..."(3); "'..they used to calm me down when it was really difficult for me to speak..."; '....if I want to go somewhere or do something, they always support me...". The participants described the support received from siblings as understanding and conversation: '...they have never reproached me for needing more time, they have always been patient..."(2); 'I talked a lot with my sister and brother... we can speak openly..." (4). The participants reported very few negative experiences with their parents: most notably lack of support, but also disregard for their difficulties or avoiding conversations about stuttering: ' '...they still think it is all in my head, that I exaggerate..." (4); "they avoided the topic..." (5).

Klompas \& Ross (2004) discovered other negative experiences concerning the impact of stuttering on the relationship with parents and siblings. Their research participants suggested that parents lacked patience and understanding, had lower expectations, and the tendency to finish sentences for their 
razumijevanja, manje očekivanje te da su imali tendenciju završavanja njihovih rečenica ukoliko bi one bile prekinute mucanjem i pridavanja više pažnje njima nego drugoj djeci, što je imalo negativan utjecaj na samopouzdanje i sam govor tih osoba. Njihov rezultat također govori i o pozitivnim iskustvima sudionika u području odnosa $\mathrm{s}$ roditeljima, pri čemu se ističe iskazivanje podrške i pružanje pomoći od strane roditelja u pogledu financiranja skupih logopedskih terapija. U pogledu utjecaja mucanja na odnos s braćom i sestrama, njihov nalaz potvrđuje rezultate ovog istraživanja jer je potvrđeno da većina sudionika ne percipira mucanje kao poteškoću u stvaranju dobrog odnosa sa svojom braćom i sestrama.

Većina sudionica govori o dobrom i odličnom odnosu s prijateljima, pružanje podrške od strane prijatelja obilježeno je strpljivošću: “... puste da kažem do kraja...” (1); “... i baš ono strpljivi su, puste me da kažem šta imam i kad mi treba duže..." (3). Ipak ističu i situacije u kojima njihovi prijatelji iskazuju i negativan stav prema njihovom mucanju: “... sjećam se toga da im se ne bi dalo čekat' ili kad su me prozvali da čitam su kao uzdisali..." (3). Kod jedne sudionice ponašanje susjeda očitovalo se do razine ruganja: “... jedan dečko iz susjedstva, to mi se urezalo u sjećanje. Rugao mi se kao: "Mucalo, mucalo..." (5)

U istraživanju Klompas i Ross (2004) tri sudionika od 16 izjavila su da mucanje nije imalo nikakav utjecaj na odnose s prijateljima (vršnjacima), dok je većina, dakle njih 13, istaknula utjecaj mucanja na odnos s prijateljima (vršnjacima) pri čemu ih nekoliko spominje i situacije ruganja zbog govora. Naše istraživanje ukazuje na zadovoljstvo odnosom s prijateljima uz povremene negativne situacije obilježene ruganjem koje možemo prepisati školskoj dobi naših sudionica i negativnim iskustvima $\mathrm{s}$ vršnjacima. Navedeno se može povezati i s pojavnosti međuvršnjačkog nasilja (Memoh, 2013.). U Hrvatskoj je prema nalazu Buljan-Flander i Šostar (2010) vršnjačko nasilje prisutno u školskom okruženju. Podaci govore da je između 40\% i $80 \%$ učenika (ovisno o vrsti nasilnih ponašanja) bar jednom doživjelo neki oblik vršnjačkog nasilja, a između 5\% i 17\% učenika gotovo svakodnevno doživljava neki od oblika nasilnog ponašanja (Reić Ergovac, 2016). Ova studija naglašava pojavnost vršnjač- children when they started to stutter. Parents also gave them more attention than their other children. This eventually affected the self-confidence and speech of children who stuttered. On the other hand, Klompas \& Ross (2004) indicated positive experiences with parents, such as support and assistance in financing expensive speech therapy. Concerning the impact of stuttering on the relationship with siblings, the findings of the abovementioned study confirmed our research results: the majority did not perceive stuttering as a barrier to a good relationship among siblings.

Most participants mentioned good or excellent relationships with friends, including support from friends in the form of patience: '.. they let me finish speaking..." (1); "...they are quite patient, they let me finish even when it takes me longer..." (3). However, they pointed out instances when their friends exhibited a negative attitude towards stuttering: "...I remember they did not like waiting or that they would sigh when I was asked to read..."

(3). For one participant, a neighbour's behaviour escalated to the point of mocking: '... there was this boy from my neighbourhood, that stuck in my mind. He mocked me: "Stutterer, stutterer" and so on..." (5).

In the research study by Klompas \& Ross (2004), three out of 16 participants suggested that stuttering had not affected their friendships with peers, whereas the majority $(n=13)$ affirmed that stuttering had affected their relationships with friends (peers); participants also recalled instances of mocking based on their speech issues. Participants in the present study indicated general satisfaction with friendships, with occasional unpleasant incidents, such as mocking during school and other negative experiences with peers. These results correlate with instances of peer violence reported by Memoh (2013). In Croatia, Buljan-Flander \& Šostar (2010) detected the presence of peer violence in the school environment. It was assumed that $40-80 \%$ of students had experienced different forms of peer violence on at least one occasion, while $5-17 \%$ of students had endured some form of violent behaviour every day (Reić Ergovac, 2016). The abovementioned study demonstrated that peer violence permeated all groups of children, including children who stut- 
kog nasilja kod svih skupina djeca pa tako i djece koja mucaju, što upućuje na izloženost negativnim ponašanjima u školskom okruženju koje treba promatrati kao odraz ukupnog stanja školske populacije djece. Kad navedeno povežemo s rezultatima svoje studije, možemo se zapitati koliko su mjere prevencije nasilja u školskom okruženju efikasne iz gledišta djece koja mucaju, ali i druge djece $s$ teškoćama obzirom na alarmantan podatak da je između 40 i 80\% učenika bar jednom doživjelo neki oblik vršnjačkog nasilja.

U britanskom istraživanju u kojem su sudjelovale odrasle osobe koje mucaju (Hugh-Jones, 1999, prema Zhang i sur., 2009) većina ispitanika napominje kako je zlostavljanje koje su proživljavali u školi imalo dugoročan negativan utjecaj na njihov život i prijateljske odnose.

Razlog zbog kojeg su osobe koje mucaju toliko stigmatizirane krije se u zanimljivom sociološkom i psihološkom fenomenu koji je opisao Boyle (2009, prema Hunsaker i Hunsaker, 2011). Po njemu stigmatizirajuća stanja i bolesti koja su na fizičkoj osnovi (poput sljepoće ili invaliditeta) u društvu se percipiraju kao nešto što osoba ne može kontrolirati te iz tog razloga zaslužuju sućut i razumijevanje, čak i naklonost. S druge strane "nevidljive" teškoće, psihičke bolesti ili poremećaji u ponašanju u društvu se gledaju kao nešto što osoba može kontrolirati, ali ne ulaže dovoljan trud te iz tog razloga zaslužuje ljutnju i osuđivanje. Prema tom načinu razmišljanja i mucanje se percipira kao nešto što osoba može kontrolirati (ili ga čak osoba sama izaziva) te dolazi do velikih predrasuda okoline, a posljedično i smanjenih šansi za razvijanje prijateljstava (Hunsaker i Hunsaker, 2011).

Sudionice iskazuju pozitivne doživljaje koje imaju iz odnosa sa partnerima te govore o dobrim iskustvima sa sadašnjim i bivšim partnerima (pružanje podrške od strane partnera): "Nikada u odnosu s partnerima nisam imala problem..." (5); "Pa nije mu bio problem.” (2); “... nije bio uopće problem, nije spomenuo da ga smeta..." (6). U manjoj mjeri govore o lošim situacijama koje se događaju u odnosu s partnerom/ima (izostanak podrške od strane partnera), navedeno povezuju s frustracijom i živčanosti kod partnera: “... i ne frustrira ga to što mucam, nego što se ne trudim...” (6); “... nekad ga živcira kad se ne trudim..." (3) tered, indicating exposure to violent behaviour in the school environment and reflecting the general situation of school-aged children. Against the backdrop of our research results, one might dispute the efficacy of violence prevention mechanisms in the school environment for children who stutter and other disadvantaged children, given the distressing indication that between $40-80 \%$ of pupils have experienced some form of peer violence on at least one occasion.

In a study involving British adults who stuttered (Hugh-Jones, 1999, in Zhang et al., 2009), most participants affirmed that the violence they had experienced in school adversely affected their lives and friendships in the long run.

The reasons behind stigmatising individuals who stutter may lie in an intriguing sociological and psychological phenomenon described by Boyle (2009) (in Hunsaker \& Hunsaker, 2011). He argued that society generally perceived, otherwise stigmatising, conditions and impairments of a physical nature (such as blindness or disability) as circumstances beyond one's control, therefore, deserving compassion and understanding, even sympathy. On the contrary, society viewed the "invisible" difficulties, such as mental illnesses or behavioural disorders as circumstances that individuals could control, but failed to make the effort to improve, which induced anger and judgement in response. Accordingly, stuttering was considered a condition that could be controlled (or even provoked by the person who stuttered), which inspired considerable prejudice from the environment, and consequently, reduced the chance of developing friendships (Hunsaker \& Hunsaker, 2011).

Participants in the present study also suggested positive experiences in relationships with partners, specifically good experiences with current and former partners (support from partners): 'I never had issues with partners..." (5); "'It was not an issue for him." (2); ' '...it was not an issue for him; he did not mention it bothered him..."(6). Participants reported very few negative experiences with partner(s) (lack of support from partners), such as the frustration and annoyance of partners: '...he is not frustrated because I stutter, but because I do not try..." (6); "'...sometimes he is annoyed that I do not try...” (3). Klompas \& Ross (2004) conducted 
Iskustva odnosa s partnerima kroz prizmu mucanja kvalitativno su istraživali Klompas i Ross (2004). Njihovo istraživanje provedeno je u Južnoafričkoj Republici sa 16 sudionika, od kojih je većina bila muškog spola. U njihovu nalazu većina sudionika ne percipira mucanje kao činjenicu koja je utjecala na odnos s partnerom/ima. Osim toga potvrđeno je i da nekoliko sudionika ima negativna iskustva u ovom području kao što su: jačanje mucanja, povlačenje u sebe, manjak povjerenja u partnera koji muca, sramoćenje, smanjeno samopouzdanje, nelagoda, manjak razumijevanja, frustracija. U našem istraživanju jedna od sudionica ističe frustraciju i iznerviranost partnera kao negativnu pojavu uzrokovanu njezinim mucanjem. U istraživanju Shearsa (1969. prema Hunsaker i Hunsaker, 2011) rezultati govore kako bi samo $7 \%$ ispitanika pristalo stupiti u brak s osobom koja muca jer ,to može biti teret za brak”. Beilby i sur. (2012) u svojoj studiji promatrali su osobe koje mucaju i njihove partnere te ustvrdili da sudionici istraživanja ne smatraju kako mucanje utječe na kvalitetu njihova života i partnerstva. Navedeno se može povezati i s rezultatima naše studije u kojoj sudionice značajno više iskazuju to da nema negativnih efekata mucanja na odnos s partnerom.

Sudionice u ovom istraživanju iskazale su nepostojanje problema oko ulazaka u romantičnu vezu, što znači da nijedna sudionica ne percipira mucanje kao prepreku za ulazak u vezu ili brak. Suprotno tome Iimura i Miyawaki (2017) u svom su istraživanju dobili rezultate koji iskazuju da njihovi sudionici smatraju mucanje velikom preprekom pri ulasku u vezu ili brak. Iimura i Miyawaki (2017) navode da ih, iako sudionici izražavaju interes za vezu ili brak, njihovo mucanje i socijalna anksioznost, kao i druge popratne pojave, sprječavaju u djelovanju u tom smjeru. Također oni navode da sudionici imaju tendenciju samootkrivanja mucanja u odnosu prema potencijalnim partnerima kako bi oni mogli razumjeti njihovo "čudno" ponašanje. O tehnici samootkrivanja mucanja pri stupanju u partnerski odnos govori i Linn (1998., prema Hunsaker, 2011) koja je dobila rezultat koji pokazuje važnost samootkrivanja za vezu jer su potencijalne partnerice kojima su muškarci koji mucaju priznali tu činjenicu percipirali dotične muškarce kao otvorenije, moćnije i privlačnije od onih muš- qualitative research on the impact of stuttering on partner relationships. Their research involved 16, mostly male, participants from the South African Republic. According to their findings, most participants did not consider that stuttering affected their relationship with partner(s). However, several participants had negative experiences in romantic relationships, including aggravated stuttering, withdrawal, lack of trust in the partner who stuttered, embarrassment, lower self-confidence, unease, lack of understanding, and frustration. In our research study, one participant mentioned the frustration and annoyance of partners among the adverse effects of stuttering. Shears (1969) (in Hunsaker \& Hunsaker, 2011.) showed that only $7 \%$ of respondents would marry a person who stuttered as "that could present a burden for the marriage". Beilby et al. (2012) studied individuals who stuttered and their partners and observed no relationships between the two groups in the perceived impact on the quality of life and the partnership. This correlates with the results of our study, where participants strongly dismissed harmful impacts of stuttering on partner relationships.

The participants of the present study had not encountered difficulties with engaging in romantic relationships, i.e., participants did not perceive stuttering as an obstacle to forming a relationship or marriage. Conversely, Iimura \& Miyawaki (2017) reported that participants perceived stuttering as a significant obstacle with respect to forming romantic relationships. Although participants were interested in forming a relationship or getting married, their stuttering, social anxiety, and other related behaviour prevented them from taking it further. Iimura \& Miyawaki (2017) also found that participants commonly revealed that they stuttered to their potential partners to account for their "strange" behaviour. Linn (1998) (in Hunsaker, 2011) also discussed the strategy of disclosing stuttering when engaging in romantic relationships. In fact, her research findings confirmed the benefits of disclosing stuttering in relationships: when men admitted they stuttered, their potential partners generally perceived them as more open, strong, and attractive compared to men who did not use this strategy. Alm (2015) corroborated these findings, claiming that individuals who were candid about 
karaca koji nisu koristili ovu tehniku. Slično iznosi i Alm (2015) jer tvrdi da osobe koje su otvorene oko svog mucanja razvijaju manje simptoma anksioznosti od onih koje sa sugovornicima ne dijele tu činjenicu o svojem govoru.

Zanimljivo je promatrati i "omjer moći” često vidljiv u brojnim romantičnim vezama iz perspektive mucanja. Nerijetko smo svjedoci da osoba koja ima veće prihode, stupanj obrazovanja, bolji posao ili status u društvu pored svog partnera izgleda nadređeno te se čini da ima veću moć (Rider, 2000, prema Nang i sur., 2018). Na sličan način mucanje, a pogotovo u odnosima u kojim žena muca, utječe na dinamiku odnosa. Kako bi sakrile svoje mucanje i odale što bolji dojam, žene koje mucaju (ŽKM) često se ponašaju na način koji zamaskiraju pod "socijalno prihvatljiv za žene" (Nang i sur., 2018). U razgovoru s partnerom većinom bi davale njemu glavnu riječ, slušale i smješkale se. Dokazano je i da ŽKM biraju za partnere osobe s pozitivnim ili neutralnim stavom o mucanju - muškarce koji ili ne mare za njihovo mucanje ili se ponašaju vrlo zaštitnički (Nang i sur., 2018).

Iz razloga što su upoznati s cjelokupnom slikom fenomena mucanja partneri osoba koje mucaju najčešće su izvrsna podrška te smatraju da ih mucanje ni na koji način ne ograničava u vezi (Beilby, 2014). Osobe koje mucaju i njihovi tečni partneri najčešće imaju slično znanje o fenomenologiji mucanja - vladaju istim saznanjima o uzrocima, terapiji, načinima nošenja s popratnim simptomima. Također partneri odraslih soba koje mucaju smatraju da i oni dijele negativna iskustva svojih partnera - oba se partnera uzrujaju pri epizodama jakog mucanja ili pri omalovažavajućim reakcijama drugih ljudi, oba partnera osjećaju anksioznost u situacijama gdje bi mucanje moglo predstavljati problem te se oba partnera mogu početi povlačiti u socijalnim situacijama (Beilby, 2014). Razlog tome je što većina partnera gleda na problem mucanja kao zajednički problem, ne kao problem samo OKM-a (Bielby i sur., 2013). Klompasa i Ross (2004) u svom radu navode kako 43,7\% ispitanika njihovog istraživanja smatra da mucanje ima negativan utjecaj na njihov bračni i obiteljski život, što znači da većina osoba koje mucaju ipak osjećaju sigurnost i zadovoljstvo u svojoj vezi. their stuttering developed fewer symptoms of anxiety compared to people who did not divulge that they stuttered to their interlocutors.

The "balance of power" in romantic relationships is highly relevant to stuttering. Individuals with higher income and education levels, better jobs, or higher social status may seem superior to their partners and, therefore, assume greater perceived power (Rider, 2000, in Nang et al., 2018). Accordingly, stuttering, particularly in relationships where a woman stutters, may affect relationship dynamics. To hide stuttering and leave a better impression, women who stutter often act in a way that appears "socially acceptable for women" (Nang et al., 2018). For example, they might let their partner lead the conversation as they listen and smile. Studies have also demonstrated that women who stutter preferred partners who had positive or neutral attitudes towards stuttering men who either ignored their stuttering or acted quite protective (Nang et al., 2018).

Since they were quite familiar with the full array of stuttering manifestations, the partners of individuals who stutter often provided exceptional support and generally considered that the stuttering did not affect their relationship (Beilby, 2014). Individual who stuttered and their partners (who spoke fluently) typically shared their knowledge on the stuttering phenomenon, including shared awareness of the causes, therapy, coping mechanisms, and secondary behaviour. Moreover, the partners of individuals who stutter also mentioned sharing unpleasant experiences with their partners: both partners got upset by instances of severe stuttering or humiliating reactions from other people; both partners experienced anxiety in circumstances when stuttering might have caused problems and they both might have started to withdraw from social interactions (Beilby, 2014). The underlying reasons were associated with the shared perception of stuttering as a mutual challenge in partner relationships rather than a difficulty faced by the individual who stuttered alone (Bielby et al., 2013). Klompas \& Ross (2004) showed that $43.7 \%$ of respondents found that stuttering affected their marital and family lives; conversely, most individuals who stuttered still felt tranquillity and satisfaction in their relationships. 
Ana Leko Krhen, Marina Milić Babić, Maja Horovskij: Izazovi i perspektive svakodnevnog života iz iskustva žena koje mucaju / Everyday...

Tablica 2. Kakva su iskustva iz područja rada i zapošljavanja žena koje mucaju? / Table 2. What are the work and employment experiences of women who stutter?

\begin{tabular}{|c|c|}
\hline TOPICS & CATEGORIES \\
\hline \multirow[t]{2}{*}{ Support from teachers during education } & Good relationship \\
\hline & Accommodations \\
\hline \multirow[t]{2}{*}{ Lack of support from teachers during education } & Refusal of oral examination \\
\hline & Compulsion to complete written examination \\
\hline \multirow[t]{2}{*}{ No attention to stuttering from superiors and colleagues } & Good relationship \\
\hline & Support \\
\hline \multirow{2}{*}{$\begin{array}{l}\text { Relevance of personality traits for employment and career } \\
\text { promotion }\end{array}$} & Severity of stuttering \\
\hline & Resourcefulness \\
\hline \multirow[t]{2}{*}{ Relevance of job demands and employers } & Type of job \\
\hline & Personality of employer \\
\hline Emotions in the workplace & Fear \\
\hline
\end{tabular}

Ipak, postoje i razilaženja u rezultatima istraživanja ove tematike. Kada su u istraživanju Beilby i suradnika (2013) partneri osoba koje mucaju bili zamoljeni da ocijene kvalitetu života svojih partnera, ocijenili su ih bolje nego što bi se OKM sami ocijenili - što ukazuje na to da je u očima partnera problem ipak nešto manji te da vide samo vrh sante leda teškoća svog partnera.

U aspektu odnosa s profesorima (Tablica 2), odgovori sudionica su podijeljeni na pozitivne $i$ dobre odnose s profesorima: "Pa većina su bili dobri, zapravo svi su bili dobri...” (3); “... uvijek punu potporu sam imala..." (4). S druge strane javlja se i izostanak podrške od strane profesora koji opisuju kroz sljedeće primjere: “... ja sam htjela da se prema meni postupa kao prema svakom drugom, a ona mi je rekla da će mi davat' da pišem." (1); “... morala sam pisat' umjesto odgovaranja ako bi im se žurilo ili nešto...” (3).

Loša iskustva odnosa s profesorima tijekom školovanja kod osoba koje mucaju pronašli su i Walden i Lesner (2018) koji su dobili nalaz o postojanju tendencije negativnog stava prema osobama koje mucaju od strane profesora i vršnjaka tijekom školovanja, odnosno o stereotipima o karakteru i ponašanju osoba koje mucaju. Ova činjenica može se smatrati vrlo sramotnom i svakako neprikladnom za obrazovni sustav jer time ne samo da se osobama koje mucaju ne daje jednaka mogućnost akademskog uspjeha već se ovdje, u slučaju nejednakog tretmana ovih osoba, može govoriti o diskriminaciji. Ukoliko se radi o djeci koja su uz navedeni problem u
On another note, a study conducted by Beilby et al. (2013) showed that the partners of individuals who stuttered rated their partners' quality of life higher than the individuals who stuttered themselves - suggesting that partners considered the challenges as less serious, and might have perceived only a fraction of the difficulties experienced by persons who stuttered.

In terms of their relationship with teachers (Table 2), the opinions of the participants differed, reflecting supportive and good relationships with teachers on one hand: 'Most of them were nice; actually, all were nice..." (3); "...I have always had full support..." (4), and a lack of support on other occasions: "...I wanted to be treated just like everyone else, but she said she would rather have me take written exams. "(1); "...I had to take written instead of oral exams when they were in a hurry or something..."(3).

Walden \& Lesner (2018) reported disagreeable experiences of people who stuttered with their teachers in educational settings, in particular, the tendency of teachers and peers to display negative attitudes towards people who stuttered, and specifically, stereotypes on their character and behaviour. These findings seem distressing and inappropriate for the education system as they may foster unequal opportunities for academic achievement, social inequality, and discrimination. Combined with financial disadvantages or social exclusion, this kind of discrimination can also leave considerable repercussions on the mental health, growth, and development of children. 
stanju financijske deprivilegiranosti ili socijalne izolacije, može doći do značajnih problema za psihičko zdravlje djeteta, kao i za njegov rast i razvoj.

Dobiveni odgovori u aspektu interpersonalnih odnosa na poslu ukazuju na izostanak važnosti mucanja kod kolega i nadređenih osoba na radnom mjestu. Sudionice govore o dobrim odnosima s kolegama, kao i sa svojim šefovima koji, ukoliko primijete mucanje kod svojih zaposlenica, ne iskazuju negodovanje zbog toga: “... imam sve veću podršku kolega s posla...” (4) “... mislim da su shvatili da nekad imam problema, da ne mogu nešto reć', ali se najnormalnije ponašaju u vezi toga...” (3). Neke sudionice govore o postojanju mucanja u odnosu s nadređenima ukoliko se radi o stresnim situacijama poput razgovora za posao ili odnosa jedan na jedan.

Klompas i Ross (2004) dobili su nešto drukčije rezultate. U njihovom istraživanju gotovo polovica sudionika izrazila je negativna iskustva što se tiče odnosa s nadređenima i kolegama u poslovnom okruženju, a teme o kojima su njihovi sudionici govorili u ovom području odnose se na pristranost evaluacije njihova rada zbog mucanja, davanje posebnog tretmana, završavanje rečenice od strane nadređenog. Pri odnosu s kolegama oni navode da sudionici također izražavaju negativna iskustva, pri čemu ističu izjavu jednog sudionika koji tvrdi da njegovi kolege uvijek preuzimaju inicijativu ili vodstvo u obavljanju aktivnosti, dok se on obično drži po strani i nastoji ne isticati. Naše sudionice izražavaju pozitivan odnos kolega prema njima i ne percipiraju da ih se tretira lošije zbog toga što mucaju.

Rezultati istraživanja Klompas i Ross (2004) i Peters i Starkwater (1989) pokazuju da sudionici u većoj mjeri ističu negativna iskustva u ovom području i da brojni poslodavci, unatoč očitim kompetencijama zaposlenika za normalno funkcioniranje u obavljanju posla, izbjegavaju pružanje mogućnosti za napredovanje zaposlenicima koji mucaju. Autori osobito ističu izjavu sudionika koji govori o propuštanju mogućnosti napredovanja zbog jačine njegova mucanja i karakteristike posla koji bi trebao obavljati, kao i izjavu drugog sudionika koji govori o izostanku napredovanja
The responses concerning interpersonal relationships at work indicated an overall irrelevance of stuttering for colleagues and superiors in the workplace. Participants reported positive relationships with colleagues and superiors who did not reproach them for stuttering: '...Colleagues at work support me increasingly..." (4); "...I think they have noticed that I sometimes have difficulties, that I cannot say something, but they act really cool about it..." (3). Some participants also recalled that stuttering occurred in interaction with superiors, particularly on stressful occasions such as job interviews or one-on-one interaction.

Klompas \& Ross (2004) obtained somewhat different results. Almost half of the participants in their study described unpleasant experiences with their superiors and colleagues at work, including biased evaluation of professional performance due to stuttering, differential treatment, as well as superiors finishing sentences for their employees. These participants also mentioned disagreeable experiences in their relationship with colleagues. In particular, one participant reported that his colleagues always took the initiative or the lead in business activities, while he generally stayed on the side lines and tried not to stand out. On the contrary, the participants in the present study considered their colleagues supportive and reported that they had not been treated poorly for stuttering.

Klompas \& Ross (2004) and Peters \& Starkwater (1989) demonstrated that participants had significantly more negative experiences in work environments, and that many employers were reluctant to extend opportunities for promotion to employees who stuttered, despite their apparent ability to meet professional demands. For example, one participant recalled forfeiting opportunities for promotion given the severity of stuttering and the expected job responsibilities. Moreover, another participant was denied promotion because his superior gave a negative appraisal of his professional performance due to stuttering.

Hurst (1983) and Opp (1997) (both in Hunsaker, 2011) attributed the decision (not) to employ or (not) to promote persons who stuttered exclusively to the employers; these decisions were typically prompted by stereotypes about their personality, lower intelligence levels, or their inability to make 
isključivo radi negativne percepcije njegova rada od strane nadređenog zbog mucanja.

Hurst (1983) i Opp (1997) (sve prema Hunsaker, 2011) govore o činjenici da su samo poslodavci oni koji donose odluku o (ne)zapošljavanju ili (ne) napredovanju osoba koje mucaju, a da je uzrok tome u stereotipima o karakteru dotičnih osoba, koji se odnose na nisku razinu inteligencije i nemogućnost donošenja brzih odluka. Zbog toga nije neobično da se osobe koje mucaju, zbog želje za neisticanjem i straha od govora nađu na nisko plaćenim, uslužnim poslovima u kojima i nemaju mogućnosti napredovanja ili razvijanja karijere. Nalaz ovog istraživanja ukazuje da sudionice percipiraju karakteristike obiju strana (i zaposlenika i poslodavca) kao bitne pri dobivanju mogućnosti za napredovanje:

“... Sve ovisi o tim šefovima jel' su neki zatucani i ono baš konzervativni i da su baš na uspjeh usmjereni skroz pa da zato misle da bi im ne'ko ko muca upropastio posao, onda normalno da te neće zaposlit' nit' će ti dat' napredovanje, al' ako su šefovi dobri ono da su usmjereni baš na zaposlenike više, a ne samo na posao da se obavi, onda će ti dat' priliku normalno k'o i kad su te zaposlili." (3) Nadalje sudionice navode: “... ukoliko netko ima puno više problema s govorom, poslodavac ako može birat' između dvoje ljudi podjednakih kvalifikacija će možda prije odabrat' onog koji nema." (1) "Moj prvi razgovor za posao nisam uspjela izgovorit' svoje ime, sigurna sam da su me odmah diskvalificirali..." (5) “... i dal' ti baš jako mucaš ono ili malo ko ja." (3) “... mislim da ima možda više ovih koji ti neće dat priliku jer baš je ono teško danas ako si drugačiji u nečem..." (2)

Sve se sudionice slažu da postoje specifični strahovi povezani s utjecajem njihova govora na svakodnevni život: strah od javnog nastupa, strah od negativnog utjecaja mucanja na napredovanje u poslu, strah od ruganja, strah od pojave mucanja: "da imam strah od javnog nastupa...” (2); “... strah od negativnog utjecaja mucanja na mogućnosti u poslu..." (4); “... osjećam često strah od pojave mucanja...” (5); “... još imam strah od ruganja..." (6)

Također sudionice govore o postojanju određenih ponašanja i emocija koji ne postoje kod osoba quick decisions. Therefore, it is not surprising that people who stutter often occupy lower-income, service-oriented positions, with limited opportunities for promotion and career development, as a consequence of their fear of standing out or speaking. The participants of the present study found that the attributes of both sides (employees and employers) influenced the opportunities for promotion:

'...It all depends on the bosses because if they are backward and conservative, and really only focused on the results, they might think that someone who stutters could harm their business; in this case, likely, they would not employ or promote you; however, if the bosses are nice, and focused more on employees, and not only on getting the job done, then, naturally, they would give you a chance, just like when they employed you."(3). The participants further observed: “...if someone had significant speech difficulties, and if the employer could choose between two people with similar qualifications, he might rather choose the person who did not have difficulties. "(1); "In my first job interview, I could not say my name, so I am sure they disqualified me immediately..." (5); "....and whether you stutter a lot, or just a little like I do." (3); ' '...I think perhaps more people would not give you a chance because it is quite difficult today if you are different in any respect..." (2).

All participants confirmed having specific fears regarding the impact of speech on daily life: fear of public speaking, fear of forfeiting promotion opportunities at work, fear of mocking, and fear of the onset of stuttering:" ... I am afraid, afraid of public speaking..." (2); "...fear of a negative impact of stuttering on job opportunities..." (4); "... I am often afraid I might start stuttering..." (5); “...I still fear mocking...” (6).

Unlike people who did not stutter, the participants recognised having distinct behavioural and emotional patterns linked to their speech and the ways it reflected on their daily activities (increased fear and stress, avoiding certain situations). They also suggested different self-help techniques for coping with stuttering that they had developed over the course of their lives (interjections, relaxation, disclosing stuttering, facing fears, religion, focusing attention, self-confidence): '...I try to do my best and mind the speech so it would not hinder 
koje ne mucaju, a koji su također povezani s njihovim govorom i načinom na koji ono utječe na obavljanje aktivnosti u životu (povećani strah i stres, izbjegavanje određenih situacija), te o različitim metodama samopomoći u suočavanju s mucanjem koje se razvijaju tijekom života (ubacivanje riječi, opuštanje, samootkrivanje, suočavanje sa strahom, vjera u Boga, usmjeravanje pažnje, samopouzdanje): “... trudim se radit' što bolje i usredotočit' na govor da me to ne koči da i ako dođe do toga da to ne bude zato što ja imam problem s govorom..." (1)

O sličnome govore i Klompas i Ross (2004) i Bajina (1995) koji su također u svojim radovima istaknuli samopouzdanje kao bitan faktor za život osobe koja muca. Loše samopouzdanje kod OKM-a može se promatrati poput začaranog kruga - OKNM smatraju da su OKM anksioznije i nižeg samopouzdanja od drugih, da imaju manje "šanse za sreću u životu" te da im je život pun prepreka, što OKM osjećaju okruženi nepodržavajućom okolinom te im na taj način potkrepljuju negativne stavove (Zhang i sur., 2009). Po istraživanju Blood (2003) 60\% ispitanika rijetko ili nikada ne priča o svom mucanju s drugima iz osjećaja nelagode. Također čak i među poznatim osobama većina osoba koje mucaju radije ne bi uopće govorili nego dopustili drugima da čuju da mucaju (Hunsaker i Hunsaker, 2011). Takav stav upućuje na nisko samopouzdanje i samosvijest oko vlastitog govora. Po istraživanju Nang i sur. (2018) žene koje mucaju imaju veći stupanj samopouzdanja od muškaraca koji mucaju. One svoje mucanje vide kao manju teškoću te samim time imaju bolju sliku o sebi. Unatoč tome i kod muškaraca i kod žena jednaka je vjerojatnost da će emotivni stres mucanja izazvati sniženo samopouzdanje, pogotovo ukoliko je udruženo $s$ negativnim reakcijama obitelji i prijatelja u ranom djetinjstvu (Nang i sur., 2018). Oni također potvrđuju postojanje različitih metoda samopomoći, odnosno načina nošenja s mucanjem, od kojih se kao najčešće ističu: drama, samopouzdanje, vježbe izgovora, psihoterapija, hipnoza, različit tempo govora, ubacivanje riječi, zamjena riječi, duboko disanje i samootkrivanje. $\mathrm{O}$ važnosti samootkrivanja govore i Breitenfeldt i Lorenz (1999. prema Klompas i Ross, 2004) i Alm (2015) u svojem radu u kojem ističu velik značaj samootkrivanja mucanja za samu osobu koja muca jer me, and if it came to that, that it was not because I had speech difficulties..."(1).

Klompas \& Ross (2004) and Bajina (1995) agreed that self-confidence played a significant role in the lives of people who stuttered. Individuals who do not stutter have found that those who do had higher levels of anxiety and lower self-confidence, "lower chances of happiness in life", and encountered more obstacles. As a result, individuals who stutter might perceive the environment as non-supportive, which reinforced their negative attitudes (Zhang et al., 2009). According to Blood (2003), $60 \%$ of respondents rarely or never spoke about their stuttering because they felt uneasy. Moreover, even famous people who stuttered preferred not to speak rather than to let others hear them stutter (Hunsaker \& Hunsaker, 2011). Such attitudes indicated low self-confidence and self-awareness about one's speech. According to Nang et al. (2018), women who stutter have higher self-confidence than men who stutter. Women perceived stuttering as a less significant hindrance and therefore had higher self-esteem. Nevertheless, both men and women were equally vulnerable to the emotional stress of stuttering that causes low self-confidence, particularly if exacerbated by negative reactions from family and friends in early childhood (Nang et al., 2018). Klompas \& Ross (2004) and Bajina (1995) ascertained that people who stuttered relied on different self-help techniques and coping mechanisms, often including drama techniques, self-confidence, pronunciation exercises, psychotherapy, hypnosis, modified tempo of speech, interjections, word substitutions, deep breathing, and disclosing stuttering. Breitenfeldt \& Lorenz (1999) (in Klompas \& Ross, 2004) and Alm (2015) highlighted the considerable benefits of disclosing stuttering: the pressure, apprehension, and stress over the interlocutor's reaction to stuttering generally builds up in the person who is attempting to hide the impairment, which, in turn, aggravates stuttering. On the other hand, open conversation about stuttering usually alleviates the stress and makes one feel relieved and more confident, which leads to more fluent speech. Carter et al. (2017) showed that acceptance is one of the most significant factors for coping with stuttering. In fact, their research participants 
Ana Leko Krhen, Marina Milić Babić, Maja Horovskij: Izazovi i perspektive svakodnevnog života iz iskustva žena koje mucaju / Everyday...

Tablica 3. Kako se doživljavaju aspekti logopedske terapije iz perspektive žena koje mucaju? / Table 3. How do women who stutter perceive different aspects of speech therapy?

\begin{tabular}{|l|l|}
\hline TOPICS & CATEGORIES \\
\hline Integrated approach to stuttering in existing treatment & Introduction of additional forms of support \\
\cline { 2 - 2 } & Inclusion of surrounding people \\
\cline { 2 - 2 } & Involvement of professionals \\
\hline Effectiveness of speech therapy & No improvement of speech \\
\cline { 2 - 2 } & Improvement of speech \\
\hline
\end{tabular}

se, u slučaju prikrivanja ovog problema, u osobi nakuplja pritisak, briga i stres oko toga što će biti ukoliko sugovornik sazna ili primijeti da osoba muca, zbog čega se i samo mucanje pojačava, dok se u slučaju govorenja o mucanju stres smanjuje i osoba se može osjećati lakše i sigurnije, što može dovesti do tečnijeg govora. Carter i sur. (2017) u govoru o načinima nošenja s mucanjem ističu prihvaćanje kao jedan od najbitnijih čimbenika koje su njihovi sudionici izdvojili pri izlaganju svog iskustva te su istaknuli da je upravo ta metoda suočavanja pomogla u povećanju kvalitete njihovog života. Carter i sur. (2017) također ističu da, iako osobama koje mucaju prihvaćanje i samootkrivanje mucanja pomaže u svakodnevnoj komunikaciji, njihova okolina može biti manje otvorena oko istoga, zbog čega se ove osobe mogu osjetiti ugroženima. Unatoč tome autori (Klompas i Ross, 2004; Carter i sur., 2017) govore o postojanju povezanosti između samoprihvaćanja potaknutog prihvaćanjem mucanja i smanjivanja negativnih utjecaja mucanja na svakodnevni život.

U aspektu terapije mucanja sve sudionice iskazale su ista ili vrlo slična mišljenja, te su istaknule da postoji velika potreba za sveobuhvatnim pogledom na mucanje i njegovu terapiju putem uvođenja novih oblika formalne podrške: “... da bi se trebalo više poradit' na psihi u tome svemu, a ne na samo tom govoru...” (1); “... obuhvatni pogled na to, a ne samo u odnosu na govor, nego i ovo unutarnje, te neke traume i strahove" (3); “... i da se nauči ljude nosit's time i kak da funkcioniraju u svakodnevnom životu, a ne samo u ordinaciji." (2) Također sve su istaknule potrebu za uključivanjem određenih osoba iz okoline i stručnjaka u same terapije kako bi se osobama koje mucaju pomoglo i u području postizanja unutarnjeg mira, a ne samo u području govora: “...uključivat' profesore... neke edukacije kako postupat', čisto da highlighted that acceptance is an efficient coping mechanism that has improved the quality of their lives. However, Carter et al. (2017) cautioned that, while individuals who stutter benefit from acceptance and disclosing stuttering in everyday interactions, they also risk a less open attitude from people in their environment, which might even appear threatening. Nevertheless, Klompas \& Ross, (2004) and Carter et al. (2017) linked self-acceptance, induced by the acceptance of stuttering, to the alleviation of the harmful effects of stuttering on the quality of everyday life.

Concerning speech therapy (Table 3), all participants shared the same or very similar opinions, highlighting a pronounced need for an integrated approach to stuttering and its treatment through new forms of formal support: '...the psychological aspect should be addressed more, not only the speech..." (1); "'... a holistic approach, not only to speaking, but also to the internal aspects, to trauma and fears "' (3); "...to teach people how to deal with this and how to manage in everyday life, not only at the clinic." (2). Furthermore, the participants stressed the need to involve people in their environment and professionals in treatment to help with their psychological difficulties along with their speech difficulties: '....include teachers... in training on how to approach this, to instruct teachers, to avert the situations when they become confused." (3); 'Well, definitely the family, parents and siblings and close people. Partner, of course... train teachers and headmasters; generally, teachers should get familiarised, through some kind of open training..." (5); “...include the business sector; maybe, this could make people realize it is not a flaw..." (4); '....somebody who stutters and still overcomes it...this person can best understand others..." (6). Participants unanimously agreed on the benefits of involving psychologists: 'I think 
se upoznaju profesori, da se ne događaju te neke situacije da su zbunjeni." (3); "Pa obitelj svakako, tipa roditelje i braću, sestre i ove bliže neke ljude. Partnera, normalno... profesore ili razrednika da se educiraju o tome i općenito treba profesore uputit u to da budu tipa neke javne edukacije..." (5); “... uključila bi i poslovno okruženje, jer možda ih može to posvijesti da mucanje nije slabost..." (4); "... netko tko sam muca i riješio je to... jer najbolje može shvatiti druge osobe..." (6) Sudionice su jednoglasne oko uključivanja psihologa: “... Pa mislim da bi trebao bit neki psiholog definitivno... da bi ti ljudi trebali popričat's nekim u vezi toga, ne tol'ko o popravljanju govora, nego o tom strahu od govora..." (4); “... a psiholog bi morao bit'... često onima koji mucaju nešto ima iza toga, znači ne znam, neka trauma ili nešto zašto mucaju pa im tu može pomoć, a i tipa ako imaju neki strah... psiholog možda i bitniji čak od logopeda jer šta ako je nekom 'ko muca više problem psihički da je baš imao neku traumu..." (3); "Definitivno psiholog... i nekakav profesor zbora... jer je upoznat s time, ja se sjećam da je naš voditelj govorio pjevajte iz dijafragme... educiran je za te neke stvari, zna porijeklo tipa može te navest da skužiš zbog čega je to, neka trauma i...” (6)

Sudionice su u ovom području govorile i o vlastitom iskustvu s logopedskim terapijama koje su pohađale tijekom života, kao i o poboljšanju tečnosti govora ili izostanku iste nakon tih terapija. Sve sudionice osim jedne pohađale su logopedsku terapiju u djetinjstvu, a prema njihovoj procjeni te terapije uopće nisu smanjile jakost njihovog mucanja (izostanak poboljšanja govora): “... ali nije to baš bilo puno nekog poboljšanja. Uglavnom je bio govor dobar tamo, ali onda u nekim svakodnevnim situacijama bi se vratio." (1); "Kod logopeda sam išla kroz cijelu osnovnu školu ja mislim i to 2 puta tjedno i iskreno nije bilo pomaka.” (2); “... znači logoped mi nije apsolutno niš' pomogao da ja nadgledam to i dalje je bilo u potpunosti isto, tako da meni nije pomoglo, ne znam kako drugim ljudima..." (2); “... bila na par terapija, ali nisu imale učinka..." (5); “... nije mi to ništa posebno pomoglo baš tamo sam super pričala, a poslije onda sve po starom.” (3); “... nisam još vidjela nikoga da je sama logopedija kao logopedija drastično pomogla, a pogotovo ljudima koji jako mucaju..." (2) it should definitely be a psychologist... people need to talk with somebody about it, not so much about improving their speech, but about this fear of speaking..." (4); “...it should be a psychologist... there is often something behind the stuttering; I do not know, some kind of trauma or some reason why they stutter; this person could help, with their fear, for example... a psychologist could even be more important than the speech-language pathologist if the person who stutters has a psychological problem, an earlier trauma..."(3); 'Definitely a psychologist...or a choir teacher...because they know about these things, I remember our teacher always used to tell us to sing from the diaphragm ...they are trained in these things, they know about the origins and can help you understand what causes it, a trauma or something else..."(6).

The participants in our study also talked about their experiences with speech therapy, as well as improvements in speech fluency or the absence of improvement after treatment. All participants, except one, attended speech therapy in childhood. In their view, it did not reduce the severity of stuttering at all (no improvement of speech): '... there was no improvement, not really. For the most part, the speech was ok there, but I had relapses in everyday situations." (1); "I went to speech therapy throughout primary school, I think twice a week, and frankly, there was not much progress." (2); '....in fact, speech therapy did not help at all, the speech basically stayed the same, so it did not help me, I do not know about others..." (2); '...I was in a couple of therapies, but they did not have any effect..." (5); ' '...It did not help me in particular; I would speak well there, and then it was back to normal afterwards." (3); '...I did not notice that the speech therapy itself helped anyone significantly, especially not the people who stuttered a lot..."(2).

Along with standard speech therapy, two participants had also attended the "VaLMod" speech therapy in the town of Varaždin, and they both believed that the severity of their stuttering had reduced considerably as a result of the therapy (improvement of speech).

In terms of the effectiveness of standard speech therapy, the present study confirmed the findings of Klompas \& Ross (2004) who had examined the 
Dvije su sudionice uz klasičnu logopedsku terapiju pohađale i terapiju mucanja "VaLMod" te obje procjenjuju da se jakost njihova mucanja drastično smanjila nakon završetka te terapije (poboljšanje govora).

Govoreći o učinkovitosti logopedskih terapija mucanja, odnosno kako je subjektivnom procjenom dobiveno u ovom radu, njihovoj neučinkovitosti, nalaz ovog istraživanja potvrđuje rezultat Klompas i Ross (2004) koji su također ispitivali utjecaj logopedskih terapija na smanjenje jakosti mucanja. $\mathrm{U}$ njihovu je radu također potvrđeno da sudionici (14 od 15) koji su pohađali logopedsku terapiju percipiraju terapiju kao neučinkovitu, suvišnu i zbunjujuću. Silverman i Zimmer (1982), koji su također potvrdili isti rezultat, ovu pojavu objašnjavaju činjenicom da u slučaju terapija provođenih tijekom djetinjstva i osnovne škole važnost i značaj te terapije može biti nešto umanjeniji zbog nezrelosti i nerazumijevanja od strane same osobe (djeteta) koja muca, dok se u slučaju pohađanja terapija kasnije u životu taj stav osobe koja muca prema terapiji mijenja jer je ta osoba sama donijela odluku o pohađanju navedene terapije i u većoj je mjeri sposobna razumjeti značenje i važnost te terapije za njezin svakodnevni život. Dok se navedena istraživanja bave percepcijom sudionika o učinkovitosti terapija mucanja, stručnjaci ostaju nesložni oko istog, a razlog tome je činjenica da još uvijek ne postoji univerzalno mjerilo za procjenu učinkovitosti (Hunsaker, 2011) jer se nije ostvario konsenzus oko toga koji se aspekti terapija trebaju proučavati i kako će se ti podaci prikupljati. Unatoč tome važno je naglasiti da se sve više naglašava važnost ispitivanja učinkovitosti terapije, ne samo u polju logopedije već i u drugim bliskim profesijama (Yaruss, 2001). Razlozi za to su brojni, a uključuju etičku odgovornost kliničara da demonstriraju učinkovitost svojih terapijskih postupaka, opravdavanje potrebe za odvajanje sredstava za pojedini terapijski pristup i slično. U području poremećaja tečnosti govora, evaluacija terapije mucanja ovisi o brojnim faktorima, a to su različite vrste terapije mucanja i filozofska neslaganja oko prirode samog poremećaja (Yaruss, 2001). Mnoge su OKM zbunjene i frustrirane jer ne znaju što sve može biti učinjeno i koje su terapije mucanja učinkovite. Također nisu svi tretmani mucanja jednako istraženi. Primjerice postoji velik broj istraživanja effects of speech therapy on reducing the severity of stuttering. Their research results demonstrated that participants (14 out of 15) who attended speech therapy perceived it as ineffective, redundant, and confusing. Silverman \& Zimmer (1982) reached the same conclusions, further interpreting the perception of ineffectiveness and irrelevance of therapy in childhood and during primary school as immaturity and an insufficient comprehension of the treatment by the person (child) who stuttered. On the other hand, individuals who attended therapy later in life adopted a different attitude as they had made a conscious decision to undergo treatment; they could thus relate to the relevance and the benefits of therapy for their everyday lives. While the abovementioned studies addressed the participants' perception of the usefulness of speech therapy, experts disagree with these conclusions. Hunsaker (2011) pointed out that a standardized benchmark for the effectiveness of speech therapy has not been established, and there is no agreement on the relevant aspects of therapy and data collection methods. However, the importance of evaluating the effectiveness of treatment has been gaining prominence in speech therapy and other related professions (Yaruss, 2001). There are many underlying reasons for that such as the ethical responsibility of clinicians to substantiate the effectiveness of their treatment procedures or to justify the allocation of resources to specific treatment approaches. From the disfluency disorder standpoint, the assessment of stuttering treatment depends on different aspects, given the various approaches to treatment and conceptual disagreements on the very essence of the disorder (Yaruss, 2001). Many individuals who stutter feel confused and frustrated as they are unfamiliar with possible interventions and the effectiveness of different approaches. Moreover, not all treatments have been studied to the same extent. For example, many research studies confirmed the effectiveness of the prolonged speech procedure in stuttering treatment, encouraging numerous clinicians to apply it for treating stuttering (Yaruss, 2001). Due to the complexity of the stuttering disorder, many clinicians have applied other approaches in stuttering treatment, shifting focus from disfluent speech patterns to address the negative effects faced by individuals who stutter. These include low self-confidence, shame, fear of speaking, and behavioural effects such as avoiding 
koja potvrđuju učinkovitost tehnike produživanja govora u terapiji mucanja, stoga mnogi kliničari u terapiji mucanja koriste upravo nju (Yaruss, 2001). Zbog kompleksne prirode mucanja velik broj kliničara koristi i druge vrste terapije mucanja od kojih se mnoge fokusiraju ne samo na netečne obrasce govora već i na negativne posljedice mucanja s kojima se mnoge OKM susreću. Samo neke od negativnih posljedica jesu nisko samopouzdanje, sram, strah od govora, bihevioralne posljedice kao što su izbjegavanje govora, određenih glasova ili govornih situacija (Yaruss, 2001). Za većinu tehnika kojima se takve negativne posljedice nastoje smanjiti, iako su preporučene $u$ različitim člancima i knjigama, nije zabilježeno koliko su zapravo učinkovite u terapiji mucanja (Cordes, 1998; Ingham i Cordes, 1999; prema Yaruss, 2001). Dakle može se zaključiti da postoji nedostatak istraživanja učinkovitosti različitih vrsta terapija mucanja koje ne ispituju površinske, već dublje komponente mucanja (Yaruss i Quesal, 2006). Razlog tomu mogla bi biti činjenica da je intrinzične aspekte mucanja, odnosno vjerovanja i osjećaje o mucanju te utjecaj mucanja na život osobe, mnogo teže definirati, a time i mjeriti od promjena u govornim ponašanjima (Yaruss i Quesal, 2006). Ipak, takvi instrumenti postoje, a mjere različite faktore kao što su govornikova tečnost u različitim govornim situacijama, samopouzdanje da će osoba održati tečnost tijekom govora u različitim situacijama, emocionalne i kognitivne reakcije na mucanje, komunikacijski stavovi i stavovi o vlastitim komunikacijskim sposobnostima te drugi faktori.

Kad se govori o učinkovitosti terapije, nužno je spomenuti i "Ahilovu petu" u terapiji mucanja, odnosno relaps mucanja. Relaps se različito definira ovisno o teorijskom okviru samog istraživača kao i o području istraživanja (Craig, 1998). Craig \& Calver (1991) ponudili su definiciju relapsa kao "mucanje do onog stupnja koji vama osobno nije prihvatljiv u trajanju od barem tjedan dana".

Craig i Hancock (1995. prema Craig 1998) u svom istraživanju navode da se i kod osoba koje mucaju i nakon uspješne terapije može pojaviti relaps mucanja. Na to se ne smije gledati kao na katastrofu ili završni čin. Kao i kod drugih poremećaja različiti ciklički procesi sasvim su prirodni pa tako i pojava relapsa kod mucanja. Logopedi koji se bave terapijom mucanja trebaju biti svjesni konstan- interactions and circumventing certain phonemes or speaking situations (Yaruss, 2001). Despite recommendations provided in numerous articles and studies, most techniques aiming to reduce such negative effects still lack an adequate assessment of effectiveness for treating stuttering (Cordes, 1998; Ingham \& Cordes, 1999 in Yaruss, 2001). Research on the effectiveness of different approaches in stuttering treatment has remained inadequate, especially studies addressing the complex aspects of stuttering in contrast to the visible manifestations (Yaruss \& Quesal, 2006). The underlying causes might pertain to the greater complexity of defining and assessing intrinsic aspects of stuttering (such as beliefs and feelings about stuttering and its impact on the lives of individuals who stutter), compared to the changes in speech behaviours (Yaruss \& Quesal, 2006). Nevertheless, there are appropriate instruments that can be used to measure different aspects, such as fluency in different speaking situations, self-confidence concerning the ability to maintain fluent speech in various situations, emotional and cognitive reactions to stuttering, communication attitudes, and attitudes about personal communication abilities.

Considering the efficacy of treatment, a relapse of stuttering appears to be its Achilles' heel. A relapse has different definitions, depending on the theoretical framework of the researchers involved and their research fields (Craig, 1998). Craig \& Calver (1991) operationally defined relapse as "stuttering to a degree which was not acceptable to yourself for at least a period of one week".

Among individuals who have been successfully treated for stuttering, a relapse should not necessarily be viewed as a disastrous and final event. As for other disorders, cycles may occur, causing swings between success, lapse, and relapse. This was suggested in a survey conducted by Craig \& Hancock 1995 (according to Craig, 1998). Clinicians who administer treatment should be aware of the struggles and difficulties that many individuals have during the management of stuttering. This should encourage patience and empathy in the clinicians (Hurt 1993). Clinicians should not be surprised when their clients experience a relapse. They should attempt to enhance motivation by discussing the relapse-success cycle and offer self-management and cognitive behavioural strat- 
tnih teškoća s kojima se susreću osobe koje mucaju, kao i moguće pojave relapsa. Sve bi ovo trebalo potaknuti strpljenje i empatiju kod logopeda (Hurt, 1993). Trebali bi pokušati motivirati osobu koja muca na diskusiji oko pojave i povlačenja relapsa i ponuditi im tehnike kognitivno-bihevioralne terapije pomoću kojih bi OKM ponovo uspostavile i održavale tečnost. Iz navedenog se može zaključiti koliko su zapravo važni follow up-terapijski sastanci kao i pohađanje grupa podrške (Craig, 1998).

\section{ZAKLJUČAK}

Rezultati ovog istraživanja potvrđuju prethodno dobivene rezultate drugih autora (Klompas i Ross, 2004; Hunsaker, 2011; Alm, 2015; Carter i sur., 2017), ali i otvaraju prostor za neke nove. Dok s jedne strane postoji tendencija dobrog odnosa $\mathrm{s}$ obitelji, prijateljima i partnerima, odnosno izostanka utjecaja mucanja na navedeno, što se vidi u kontekstu pružanja podrške, s druge strane neke sudionice ipak prijavljuju da imaju i negativna iskustva u ovom području, a koja se uglavnom odnose na umanjivanja značaja mucanja od strane bliskih osoba ili frustraciju izazvanu mucanjem. Unatoč tome što sudionice s ovim problemom žive dugi niz godina, one prijavljuju postojanje određenih negativnih pojava koje su povezane isključivo s mucanjem. Neke od njih su: strah od ruganja, pojačani strah od javnog nastupa ili razgovora $\mathrm{s}$ nadređenima na poslu, a najviše se ističe postojanje područja svakodnevnog života u kojima mucanje sudionicama istraživanja još uvijek predstavlja velik problem, poput telefoniranja ili predstavljanja i upoznavanja. U pogledu poslovnog i akademskog života sudionice većinom govore o postojanju pozitivnih iskustava u odnosima s kolegama, nadređenima, profesorima i vršnjacima u školi, no također su prisutne i situacije koje su dovele do negativnih iskustava u ovom području. Te se situacije odnose na poteškoće s usmenim odgovaranjem i izlaganjem u školi zbog čega su bile primorane koristiti prilagođene metode polaganja usmenih ispita, nametnutih od strane nastavnika, poput pismenog odgovaranja, no unatoč tome većina negira utjecaj mucanja na akademski uspjeh. Osim toga sudionice iskazuju postojanje odličnog odnosa s kolegama i klijentima u poslovnom okruženju te naglašavaju da u većini slučajeva dotične egies to help regain and maintain fluency skills. They should also emphasize the value of attending follow-up sessions, adhering to practice schedules, and joining self-help groups (Craig, 1998).

\section{CONCLUSION}

This research study has confirmed the findings of previous studies (Klompas \& Ross, 2004; Hunsaker, 2011, Alm, 2015; .Carter et al., 2017) and offered certain new insights. As observed from the support available, the participants generally maintained good relationships with family, friends, and partners, which were not significantly affected by stuttering. However, some participants reported unpleasant experiences in this domain, such as disregard for or frustration with stuttering from people close to them. Although participants had lived with this issue for many years, they still reported certain negative aspects associated with stuttering. These included a fear of mocking, an intense fear of public speaking, or talking to superiors at work. In particular, everyday activities that continued to present considerable challenges for individuals who stuttered included telephone conversations, and presenting or introducing themselves to new people. With respect to professional and educational experiences, the participants mentioned good relationships with colleagues, superiors, teachers, and peers at school. However, they reported certain unpleasant experiences involving differential treatment in oral examinations and presentations by teachers who imposed alternatives to oral exams, including recourse to the written examination. Despite this, most participants argued that stuttering had not affected their educational achievements. Furthermore, the participants described excellent relationships with colleagues and clients at work who generally did not notice their impairment. Therefore, the participants in our study concluded that stuttering did not present significant challenges for their professional activities. Moreover, none of the participants implied that stuttering had influenced their choice of occupation. Nevertheless, the participants agreed that there were certain career choice limitations for people who stuttered, especially with respect to jobs that required advanced verbal competences, such as radio presenters or managers in large corporations. At the same time, our results indicated similar 
osobe nisu primijetile poteškoće s govorom zbog čega smatraju da im mucanje ne predstavlja drastičan problem u poslovnom svijetu, a što se vidi i iz činjenice da nijedna sudionica nije potvrdila utjecaj mucanja na izbor svog zanimanja. Unatoč tome sudionice su složne u mišljenju da su osobe koje mucaju ograničene pri izboru posla u pogledu izostanka mogućnosti za zapošljavanje na radnim mjestima koja zahtijevaju izrazite verbalne sposobnosti, poput radijskog voditelja ili menadžera u velikoj korporaciji. Također rezultati ukazuju na postojanje sličnih stavova oko mogućnosti dobivanja posla ili napredovanja u odnosu na osobe koje ne mucaju, pri čemu ističu da navedeno ne ovisi samo o karakteristikama željenog radnog mjesta i poslodavca (konzervativnost poslodavca, zahtjevnost radnog mjesta), već i o karakteristikama osobe kao što su jakost mucanja, radišnost i snalažljivost.

$\mathrm{U}$ pogledu iskustava s pohađanjem terapija mucanja dobiven je vrlo zanimljiv nalaz. Sudionice su složne u mišljenju da je logopedska terapija, iako pruža kratkotrajno olakšanje u pogledu tečnijeg govora, neučinkovita u uklanjanju mucanja veće jakosti. Razlog tome vide u principu same terapije koja se obavlja u "zaštićenom" okruženju koje ne pruža mogućnost usvajanja tehnika sprečavanja mucanja u svakodnevnim situacijama stresa. Stoga ističu da veliku važnost za smanjivanje jakosti mucanja i/ili potpunu rehabilitaciju govora nude programi koji osobama koje mucaju nude mogućnosti učenja tehnika tečnog govora, primjenjivih u svim govornim situacijama. Bothe i sur. (2006) dali su sustavan prikaz uspješnosti različitih tretmana mucanja kod djece i odraslih te došli do zaključka da adolescenti i odrasli najviše koristi imaju od tehnike produživanja govora. Čini se da su ključ uspjeha primjena produživanja govora u kombinaciji sa self-managmentom, održavanjem izvedbe i infrastrukturalne varijable.

Mucanje sa sobom nosi brojne negativne posljedice, pa se tako osoba koja muca često susreće $s$ negativnom percepcijom i reakcijama svojih vršnjaka kroz zadirkivanje, stereotipe pa čak i zlostavljanje. Također osoba koja muca s vremenom može stvoriti negativnu percepciju o vlastitim komunikacijskim sposobnostima, strah od komunikacije i negativne evaluacije od strane drugih. Sve ovo pogoduje razvoju negativnih emocija, kao i socijalne anksioznosti koja je nerijetko glavni attitudes on the opportunities for employment or promotion compared to people who did not stutter; these opportunities depended not only on the responsibilities associated with the aspired position and the employers (e.g., conservative attitude of employers, job complexity), but also on personality traits, including the severity of stuttering, diligence, and resourcefulness of people who stuttered.

Finally, this study provided important insights on the experiences of participants with speech therapy. The participants agreed that speech therapy generally proved ineffective in addressing severe stuttering, although it did offer a short-term alleviation in terms of improved speech fluency. This could be due to the very principles of this therapeutic approach, which evolved in a "protected" environment and thus did not provide training in strategies for preventing stuttering in everyday stressful occasions. Therefore, people who stuttered pointed out that treatments applicable to everyday speaking situations, such as those that allowed learning about the techniques to achieve fluent speech, seemed more efficient in moderating stuttering and/or full speech rehabilitation. Bothe et al. (2006) systematically presented the efficacy of different stuttering treatments for children and adults and concluded that adolescents and adults seemed to benefit most from prolonged speech procedures. These procedures, in combination with self-management, performance-contingent maintenance, and infrastructural variables, appear to be the key to success.

Stuttering can results in a number of harmful side effects: individuals who stutter typically face unfavourable perceptions and reactions from their peers, such as teasing, stereotypes, and even abuse. Furthermore, they may cause negative perceptions of their communication abilities over time and develop a fear of communication and negative appraisal by others. These factors generate negative emotions and social anxiety, which are often the principal motivation for engaging in stuttering treatment. In the case of stuttering, anxiety is linked to social interaction involving speech. Therefore, an assessment of anxiety and the presence of negative emotions is pivotal in the evaluation and treatment of stuttering, even if the stuttering is mild. Taking these aspects into consideration is crucial 
motiv ulaska u terapiju mucanja. Anksioznost kod mucanja svojstvena je društvenim situacijama koje uključuju govor, stoga je iznimno važno u procjeni i terapiji mucanja, čak i kod slučajeva stupnja težine blagog mucanja, procijeniti anksioznost $i$ postajanje negativnih emocija. Važno ih je uzeti u obzir jer ponekad njihova prisutnost može predstavljati veći problem od samih govornih netečnosti za osobu koja muca. Također njihova prisutnost može "kočiti" uspjeh terapije mucanja, te je tada potrebno u suradnji sa stručnjacima kao što su psiholozi, uzeti u obzir i druge pristupe kao što je kognitivno-bihevioralna terapija. U istraživanju Menzies i sur. (2009) otkriveno je da je kognitivno-bihevioralna terapija učinkovita u smanjivanju anksioznosti i socijalnog izbjegavanja kod OKM-a te pomaže u povećavanju samopouzdanja OKM-a. Pozitivne promjene u komunikacijskim stavovima OKM-a potvrđene su i u Acceptance and commitment-terapiji, kao i u terapiji Comprehensive Stuttering Program. Sve navedeno upućuje na to da dobivanje govora koji je tečan nije dostatno za maksimalan uspjeh u logopedskoj terapiji mucanja. Od jednake važnosti kao i rad na tečnosti govora jest i rad na komunikacijskim stavovima OKM-a, kao i na njihovoj percepciji vlastitih sposobnosti komuniciranja (Guttormsen i sur., 2015).

Vrijednost ovog istraživanja može se ogledati i u činjenici da je ovo prvo kvalitativno istraživanje u Hrvatskoj sa ženama koje mucaju, usmjereno na iskustva iz privatnog života, rada i zapošljavanja te rehabilitacije govora. Nedostaci istraživanja ogledaju se u relativno malom uzorku od šest žena, te se ne mogu poopćavati na cjelokupnu populaciju osoba koje mucaju. Ipak, rezultati su važni jer pristižu iz gledišta žena koje mucaju dajući nam jasniju sliku o njihovim iskustvima iz privatne $i$ poslovne sfere, ali i rehabilitacije koju su prolazile osobno. Izneseni rezultati mogu poslužiti logopedima u praksi za unaprjeđenje sustava podrške, ali i samim osobama koje mucaju u smislu dobivanja uvida u to kako je to kod drugih osoba koje se suočavaju s mucanjem. Buduća istraživanja trebala bi obuhvatiti veći uzorak i žena i muškaraca, ali i njihovih partnera, članova obitelji te poslodavca i radnih kolega, a u konačnici i stručnjaka koji pružaju različite oblike rehabilitacijskih usluga u praksi kako bi se dobile perspektive svih dionika. as they may pose greater challenges for the person who stutters than speech disfluencies, subsequently hindering the effectiveness of stuttering treatment. Therefore, other approaches, such as cognitive behavioural therapy, must be considered, especially since it involves other professionals such as psychologists. According to Menzies et al. (2009), cognitive behavioural therapy can efficiently alleviate anxiety and social avoidance, as well as increase self-confidence in individuals who stutter. Positive shifts in communication attitudes among individuals who stutter are also necessary for the "acceptance and commitment" treatment, as well as the Comprehensive Stuttering Programme. These findings indicate that attaining speech fluency does not represent the pinnacle of success in speech therapy. It is equally important to transform communication attitudes and the perception of personal communication abilities along with improving speech fluency (Guttormsen et al., 2015).

This study represents the first qualitative research on the experiences of women who stutter in Croatia: we examined the effect of stuttering on their personal life, work, employment, and speech rehabilitation experiences. The limitations of this study include a relatively small sample involving six women, which prevents the generalisability of the results to all individuals who stutter. Nevertheless, our results are relevant since they present the women's perspective on stuttering and offer a unique impression of their personal, professional, and treatment-related experiences. These results can help speech-language pathologists improve support mechanisms and offer an insight into the experiences of people who struggle with stuttering. Further research must be conducted with a larger sample of men, women, and their partners, family members, employers, and colleagues; studies must also include professionals who provide different rehabilitation services to individuals who stutter in order to collect relevant perspectives from all stakeholders. 


\section{REFERENCES}

Alm, P.A. (2015). Is it Thinking and not Feeling that Influence Variability of Stuttering in Social Situations? About Stuttering and Social Cognition. Procedia - Social and Behavioral Sciences, 193, 289-290.

Ambrose, N., Cox, N., \& Yairi, E. (1997). The genetic basis of persistence and recovery in stuttering. Journal of Speech, Language and Hearing Research 40 (3), 567-580.

American Psychiatric Association (APA). (2013). Diagnostic and statistical manual of mental disorders (5th ed.). Washington, DC: APA.

Andrijolić, A., Leko Krhen, A. (2016). Diferencijalna dijagnostika poremećaja tečnosti govora [Differential diagnostics of the fluency disorder]. Hrvatska revija za rehabilitacijska istraživanja, 52 (2), 60-72.

Aslihan, I. (2011). Stuttering. Current Approaches in Psychiatry, 3(4), 704-728.

Bajina, K. (1995). Covert aspects associated with the 'stuttering syndrome': Focus on self-esteem. U Fawcus, M. (ed.), Stuttering from theory to practice. London: Whurr Publishers Ltd.

Beilby, J.M. Byrnes, M.L., Meagher, E. L. and Yaruss, J. S. (2012).The impact of stuttering on adults who stutter and their partners. Journal of Fluency Disorders. 38(1); 14-29

Bloodstein, O. and Bernstein Ratner, N. (2008). A handbook on stuttering. New York: Delmar.

Blomgren, M. (2010). Stuttering treatment for adults: an update on contemporary approaches. Semin Speech Lang, $31(4), 272-282$.

Blumgart, E., Tran, Y., andCraig, A. (2014). Social support and its association with negative affect in adults who stutter. Journal of Fluency Disorders, 40, 83- 92

Bothe, A. K., Davidow, J. H., Bramlett, R. E., \& Ingham, R. J. (2006). Stuttering treatment research 1970-2005: I. Systematic review incorporating trial quality assessment of behavioral, cognitive, and related approaches. American Journal of Speech-Language Pathology, 15, 321-341.

Behavioral Stuttering Interventions for Children and Adolescents: A Systematic Review and Meta-Analysis. Available from: https://www.researchgate.net/publication/234012054_Behavioral_Stuttering_Interventions_for_Children_ and_Adolescents_A_Systematic_Review_and_Meta-Analysis [accessed Mar 28 2021].

Boyle, M. P. (2015). Relationships between psychosocial factors and quality of life for adults who stutter. American Journal of Speech-Language Pathology, 24, 1-12.

Buljan-Flander, G. \& Šostar, Z. (2010). Nasilje među djecom [Violence among children]. Accessed on 29.07.2019. at https://www.poliklinika-djeca.hr/publikacije/nasilje-medu-djecom-2/

Carter, A., Breen, L., Yaruss, J. S. \& Beilby, J. (2017). Self-efficiacy and quality of life in adults who stutter. Journal of Fluency Disorders, 54, 14-23.

Chang, S. E., Erickson, K.I., Ambrose, N. G., Hasegawa-Johnson, M. A., Ludlow, C. L. (2008). Brain Anatomy Differences in Childhood Stuttering. Neuroimage. 39(3): 1333-1344. doi:10.1016/j.neuroimage.2007.09.067.

Chang, S. E., Garnett, O. E., Etchell, A., Ming Chow (2018). Functional and Neuroanatomical Bases of Developmental Stuttering: Current Insights. The Neuroscientist 25(6) 566-592

Connally E, Ward D, Howell P, Watkins KE (2013). Disrupted white matter in language and motor tracts in developmental stuttering. Brain and Language. 131:25-35.

Craig, A., \& Hancock, K. (1995). Self-reported factors related to relapse following treatment for stuttering. Australian Journal of Human Communication Disorders, 23(1), 48-60.

Craig, A., Hancock, K., Tran, Y., Craig, M., Peters, K. (2003). Anxiety levels in people who stutter: A randomized population study. Journal of Speech Language and Hearing Research, 46, 1197-1206. 
Craig, A., \& Tran, Y. (2006). Fear of speaking: chronic anxiety and stammering. Advances in Psychiatric Treatment, 12(1), 63-68.

Duranović, M., Begić, L., Jovanović-Simić, N., \& Rahmanović, D. (2018). Komunikacija i mucanje [Communication and stuttering]. Accessed on 5.5.2019 at http://erf.untz.ba/web/wp-content/uploads/2018/10/Komunikacija-i mucanje.pdf

Ezrati-Vinacour, R., \& Levin, I. (2004). The relationship between anxiety and stuttering: A multidimensional approach. Journal of Fluency Disorders, 29(2), 135-148.

Galić-Jušić, I. (2001). Što učiniti s mucanjem: cjelovit pristup govoru i psihi [How to handle stuttering: an integrated approach to speech and psyche]. Lekenik: Ostvarenje.

Guitar, B. (2014). Stuttering. An Integrated Approach to Its Nature and Treatment. Fourth Edition. Baltimore: Lippincott Williams \& Wilkins, a Wolters Kluwer business.

Guttormsen, L. S., Kefalianos, E., Næss, K. A. B. (2015). Communication attitudes in children who stutter: A metaanalytic review. Journal of Fluency Disorders, 46, 1-14.

Hunsaker, S. (2011). The Social Effects of Stuttering in Adolescents and Young Adults. Doktorska disertacija. Illinois: Southern Illinois University Carbondale.

Iverach, L., Jones, M., O’Brian, S., Block, S., Lincoln, M., Harrison, E., ... \& Onslow, M. (2009). Screening for personality disorders among adults seeking speech treatment for stuttering. Journal of Fluency Disorders, 34(3), 173-186.

Limura, D. \& Miyawaki, M. (2017). An exploratory research study about the influence of stuttering on romantic relationships. The Japan Journal of Stuttering and other Fluency Disorders, 1(1), 1-12.

Iimura, D. (2017). An Investigation of Work Life and Reasonable Accommodation among Adults who Stutter. Japan Journal of Logopedics and Phoniatrics, 58(3), 205-215.

Kasbi, F., Mokhlesin, M., Maddah, M., Noruzi, R., Monshizadeh, L., Khani, M.M.M. (2015). Effects of Stuttering on Quality of Life in Adults Who Stutter. Middle East Journal of Rehabilitation and Health, 2(1), 1-6.

Kelman, E. and Wheeler, S. (2015): Cognitive Behaviour Therapy with children who stutter. Procedia-Social and Behavioral Sciences, 193, 165-174.

Kessler, R. C., Berglund, P., Demler, O., Jin, R., Merikangas, K. R., \& Walters, E. E. (2005). Lifetime prevalence and age-of-onset distributions of DSM-IV disorders in the National Comorbidity Survey Replication. Archives of general psychiatry, 62(6), 593-602.

Klein, J. F. and Hood, S. (2004) The Impact of Stuttering on Employment Opportunities and Job Performance. Journal of Fluency Disorders 29(4):255-73.

Klompas, M. \& Ross, E. (2004). Life experiences of people who stutter, and the perceived impact of stuttering on quality of life: personal accounts of South African individuals. Journal of Fluency Disorders, 29, 275-305.

Manning, W. H. (2010): Clinical Decision Making in Fluency Disorders (Third edition). Delmar Cengage Learning: International Edition.

Memoh, C. N. (2013). An investigation of the different forms of bullying amongst grade 10 learners in South Afrrican schools: a case study of three schools in the Western Cape. Diplomski rad. Western Cape.

Menzies, R. G., Onslow, M., Packman, A., O’Brian, S. (2009). Cognitive behavior therapy for adults who stutter: a tutorial for speech-language pathologists. Journal of Fluency Disorders.34(3):187-200. DOI: 10.1016/j. jfludis.2009.09.002.

Menzies, R. G., Onslow, M. and Packman, A. (1999). Anxiety and Stuttering: Exploring a Complex Relationship. American Journal of Speech-Language Pathology, 8, 3-10.

Milton, K. (2013). Women who stutter: experiences of developing self-management and quality of life. Edith Cowan University. Accessed on 16.03.2021. at https://ro.ecu.edu.au/cgi/viewcontent.cgi?article=1089\&context=theses_hons 
Nang, C., Hersh, D., Milton, K., \& Lau, S. R. (2018). The impact of stuttering on development of self-identity, relationships, and quality of life in women who stutter. American journal of speech-language pathology, 27(3S), 1244-1258.

Peters, H. F., \& Starkweather, C. W. (1989). Development of stuttering throughout life. Journal of Fluency Disorders, 14(5), 303-321.

Plexico, L., Manning, W.H., \& Levitt, H. (2009). Coping responses by adults who stutter: part I. Protecting the self and others. Journal of Fluency Disorders, 34(2), 87- 107

Reić Ercegovac, I. (2016). Doživljeno vršnjačko nasilje: relacije s dobi, spolom, razrednim ozračjem i školskim uspjehom [Experienced peer violence: relation to age, sex, class environment and achievement]. Školski vjesnik : časopis za pedagogijsku teoriju i praksu, 65(2): 251-271.

Sardelić, S., Brestovci, B., \& Hedever, M. (2001). Karakteristične razlike između mucanja i drugih poremećaja fluentnosti govora [Characteristic differences between stuttering and other speech fluency disorders]. Govor, 18(1), 45-60.

Shapiro, D. A. (2011). Stuttering Intervention: A Collaborative Journey to Fluency Freedom, 2nd Edition. Austin: Pro-Ed.

Schneier, F. R. (2003). Social anxiety disorder. BMJ 2003; 327 doi: https://doi.org/10.1136/bmj.327.7414.515

Silverman, E. M., \& Zimmer, C. H. (1982). Demographic characteristics and treatment experience of women and men who stutter. Journal of Fluency Disorders, 7, 273-285.

Škarić, I. (1988). Govorne poteškoće i njihovo uklanjanje [Speech difficulties and their treatment]. Zagreb: Mladost.

Theys, C., Van Wieringen, A., De Nil, L. F. (2008). A clinician survey of speech and non-speech characteristics of neurogenic stuttering, Journal of Fluency Disorders, 33, 1-23.

Theys, C., Van Wieringen, A., Tuyls, L., De Nil., L. (2009). Acquired stuttering in a 16-year-old boy, Journal of Neurolinguistics, 22, 427-435.

Theys, C., Van Wieringen, A., Sunaert, S., Thijs, V., De Nil, L. F. (2011): A one-year prospective study of neurogenic stuttering following stroke: incidence and co-occurring disorders, Journal of Communication Disorders, 44, 678-687.

Van Borsel, J. (2014). Acquired stuttering: A note on terminology, Journal of Neurolinguistics, 27, 41-49.

Van Borsel, J., Taillieu, C. (2001): Neurogenic stuttering versus developmental stuttering: An observer judgement study, Journal of Communication Disorders, 34, 385-395.

Višaticki Jakovljević, T. (2018). Utjecaj mucanja na kvalitetu života odraslih osoba koje mucaju. (Diplomski rad) [Impact of stuttering on the quality of life of adults who stutter]. (Master thesis). Zagreb: Edukacijskorehabilitacijski fakultet.

Walden, T. A. \& Lesner, T. A. (2018). Examining implicit and explicit attitudes toward stuttering. Journal of Fluency Disorders. 57, 22-36.

Ward, D. (2010). Sudden onset stuttering in an adult: Neurogenic and psychogenic perspectives, Journal of Neurolinguistics, 23, 511-517.

Yairi, E. and Seery, C.H. (2015). Stuttering: Foundations and Clinical Applications, 2nd Edition. Harlow: Pearson Education Limited.

Yaruss, J. S. (2010). Assessing quality of life in stuttering treatment outcomes research. Journal of Fluency Disorders, $35,190-202$.

Zhang, J., Saltuklaroglu, T., Hough, M., \& Kalinowski, J. (2009). Jobs, sex, love and lifestyle: When nonstutterers assume the roles of stutterers. Folia Phoniatrica et Logopaedica, 61(1), 18-23. 